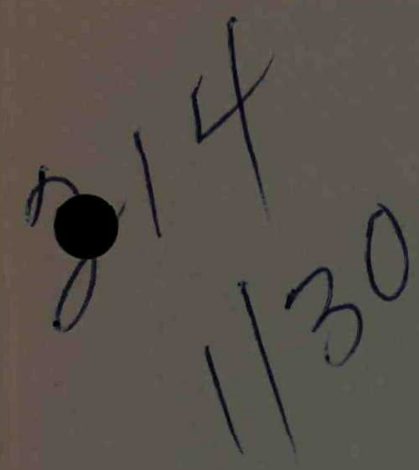

637

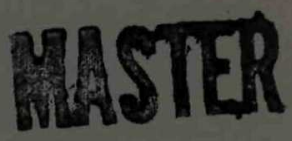

ORNL-4357

UC-4 - Chem istry

\title{
CURIUM DATA SHEETS
}

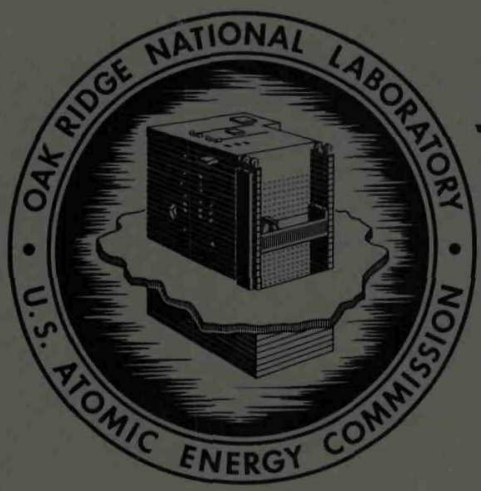

OAK RIDGE NATIONAL LABORATORY

$$
\text { operated by }
$$

UNION CARBIDE CORPORATION

$$
\text { for the }
$$

U.S. ATOMIC ENERGY COMMISSION 
Printed in the United Stotes of America. Available from Clearinghouse for Federal Scientific and Technical Information, National Bureau of Standards,

U.S. Department of Commerce, Springfield, Virginia 22151

Price: Printed Copy $\$ 3.00$; Microfiche $\$ 0.65$

LEGAL NOTICE

This report was prepared as an account of Government sponsored work. Neither the United States, nor the Commission, nor any person acting on behalf of the Commission:

A. Makes any warranty or representation, expressed or implied, with respect to the accuracy, completeness, or usefulness of the information contained in this report, or that the use of any information, apparatus, method, or process disclased in this report may not infringe privately owned rights; or

B. Assumes any liabilities with respect to the use of, or for damages resulting from the use of any information, apparatus, method, or process disclased in this report.

As used in the above, "person acting on behalf of the Commission" includes any employee or contractor of the Commission, or employee of such contractor, to the extent that such employee or contractor of the Commission, or employee of such contractor prepares, disseminates, or provides access to, any information pursuant to his employment or contract with the Commission, or his employment with such contractor. 


\section{DISCLAIMER}

This report was prepared as an account of work sponsored by an agency of the United States Government. Neither the United States Government nor any agency Thereof, nor any of their employees, makes any warranty, express or implied, or assumes any legal liability or responsibility for the accuracy, completeness, or usefulness of any information, apparatus, product, or process disclosed, or represents that its use would not infringe privately owned rights. Reference herein to any specific commercial product, process, or service by trade name, trademark, manufacturer, or otherwise does not necessarily constitute or imply its endorsement, recommendation, or favoring by the United States Government or any agency thereof. The views and opinions of authors expressed herein do not necessarily state or reflect those of the United States Government or any agency thereof. 


\section{DISCLAIMER}

Portions of this document may be illegible in electronic image products. Images are produced from the best available original document. 


\section{LEGAL NOTICE}

This report was prepared as an account of Government sponsored work. Neither the United States, nor the Commission, nor any person acting on behalf of the Commission:

A. Makes any warranty or representation, expressed or implied, with respect to the accuracy, completeness, or usefulness of the information contained in this report, or that the use of any information, apparatus, method, or process disclosed in tbis report may not infringe of any information, appara
privately owned rights; or

B. Assumes any liabilities with respect to the use of, or for damages resulting from the of any information, apparatus, method, or process disclosed in this report.

As used in the above, "person acting on behalf of the Commission" includes any employee or contractor of the Commission, or employee of such contractor, to the extent that such employee or contractor of the Commission, or employee of such contractor prepares, disseminates, or provides access to, any information pursuant to his employment or contract with the Commission, or his employment with such contractor.

Contract No. W-7405-eng-26

ISOTOPES DEVELOPMENT CENTER

CURIUM DATA SHEETS

S. J. Rimshaw

E. E. Ketchen

Isotopes Division

JANUARY 1969

OAK RDGE NATIONAL LABORATORY

Oak Ridge, Tennessee

operated by

UNION CARBIDE CORPORATION

for the

U.S. ATOMIC ENERGY COMMISSION 
-

0 
I. CURIUM-244 . . . . . . . . . . . . . . . . . . I

A. CURIUM-244 METAL .................... . . . . I

1. Composition ................... 1

2. Specific Power . . . . . . . . . . . . . 2

3. Radiation ................... 2

4. Critical Mass . . . . . . . . . . . . . 5

5. Compatibility with Materials of Containment . . . . 6

6. Thermophysical Properties ............ 6

7. Mechanical Properties .............. . 7

8. Chemical Properties . . . . . . . . . . . . 8

9. Biological Tolerances . . . . . . . . . . . . 8

10. Shielding Data... . . . . . . . . . . . . . 9

B. CURIUM SESQUIOXIDE $\left(\mathrm{Cm}_{2} \mathrm{O}_{3}\right) \cdot$. . . . . . . . . . . . 13

1. Composition ................. 13

2. Specific Power ............... . 13

3. Radiation ................ . . 13

4. Critical Mass ................ . 13

5. Compatibility with Materials of Containment . . . . 13

6. Thermophysical Properties ............. 13

7. Mechanical Properties . . . . . . . . . . . . 17

8. Chemical Properties . . . . . . . . . . . . . 17

9. Biological Tolerances .............. . 18

10. Shielding Data . . . . . . . . . . . . 18

C. CURIUM OXYSULFIDE $\left(\mathrm{Cm}_{2} \mathrm{O}_{2} \mathrm{~S}\right)$. . . . . . . . . . . . . . 19

1. Composition . . . . . . . . . . . . . 19

2. Specific Power . . . . . . . . . . . . . 19

3. Radiation .................. . 19

4. Critical Mass .. . . . . . . . . . . . . 19

5. Compatibility with Materials of Containment . . . . 19

6. Thermophysical Properties .. . . . . . . . . 19

7. Mechanical Properties .............. 21

8. Chemical Properties .. . . . . . . . . . . 21

9. Biological Tolerances . . . . . . . . . . . . 21

10. Shielding Data............... . . 21

D. CURIUM FLUORIDE $\left(\mathrm{CmF}_{3}\right)$. . . . . . . . . . . . . . 22

1. Composition .................. . 22

2. Specific Power . . . . . . . . . . . . 22

3. Radiation ................. . 22

4. Critical Mass ................. 22

5. Compatibility with Materials of Containment . . . . 22

6. Thermophysical Properties ............. 22

7. Mechanical Properties ............. 24

8. Chemical Properties ............... 24

9. Biological Tolerances ............. 24

10. Shielding Data... .......... . . 24 
II. CURIUM-242 . . . . . . . . . . . . . . . . . 25

A. CURIUM-242 OXIDE CERMET . . . . . . . . . . . 25

1. Composition ................ . 25

2. Specific Power . . . . . . . . . . . . . 26

3. Radiation ............... 26

4. Critical Mass . . . . . . . . . . . . . 30

5. Compatibility with Materials of Containment . . . . 30

6. Thermophysical Properties . . . . . . . . 30

7. Mechanical Properties ............. . 30

8. Chemical Properties.............. . . 30

9. Biological Tolerances . . . . . . . . . . . 30

10. Shielding Data . . . . . . . . . . . . . 31

III. REFERENCES FOR CURIUM . . . . . . . . . . . . . 34 
I. CURIUM-244
A. CURIUM-244 METAI
Half-life: 18.1 y
1,2

1. Composition

a. Radionuclidic abundance

The anticipated isotopic composition of ${ }^{244} \mathrm{Cm}$ product resulting from a large-scale production program is represented by the actual isotopic composition of the first product batch resulting from the 1968-1969 SRL campaign shown below. The mass spectrographic analysis yielding these data was performed 18 months after reactor discharge.

\begin{tabular}{cc} 
Isotopic Composition of Curium Product \\
\hline Isotopic mass & $\%$ Abundance \\
\cline { 2 - 2 } 242 & 0.043 \\
243 & 0.024 \\
244 & 95.08 \\
245 & 0.729 \\
246 & 4.02 \\
247 & 0.066 \\
248 & 0.038
\end{tabular}

b. Radiochemical purity

The ${ }^{244} \mathrm{Cm}$ product will contain small amounts of fission products formed in the irradiation process and not removed in the chemical separations process. From the predicted performance of the chemical process and the calculated quantities of fission products associated with the curium after irradiation, the gamma activities of the fission-product impurities can be calculated and are tabulated in the table in Section I.A.3.c. (page 3) in the column labeled "From Impurities." Almost all of the gamma rays above $1 \mathrm{Mev}$ are from ${ }^{144} \mathrm{Pr}$ and ${ }^{152-154} \mathrm{Eu}$, and those below $1 \mathrm{Mev}$ are primarily from $95 \mathrm{Zr}-{ }^{95} \mathrm{Nb}$, ${ }^{144} \mathrm{Ce},{ }^{106} \mathrm{Rh}$, and ${ }^{103} \mathrm{Ru}-{ }^{103} \mathrm{Rh}$.

Fission products will also be formed by the spontaneous fission of ${ }^{244} \mathrm{Cm}$ and ${ }^{252} \mathrm{Cf}$, which is present at an estimated maximum of $4 \times 10^{-5}$ wt $\%$ of the ${ }^{244} \mathrm{Cm}$. The gamma activities from these two isotopes are tabulated under the columns labeled "From Fission Products of ${ }^{244} \mathrm{Cm}$ and ${ }^{252} \mathrm{Cf}$."

Americium-243 and ${ }^{252} \mathrm{Cf}$ which are formed in the irradiation process are removed during chemical processing except for an estimated 0.5 wt $\%{ }^{243} \mathrm{Am}$ and $<4 \times 10^{-5}$ wt $\%$ ${ }^{252} \mathrm{Cf}$ in the ${ }^{244} \mathrm{Cm}$ product. 
c. Chemical purity

The following elemental impurity limits have been set as objectives for the ${ }^{244} \mathrm{Cm}$ process by Savannah River Plant during the CY 1968-1969 campaign:

Elemental impurities

$\mathrm{Li}+\mathrm{Na}+\mathrm{K}$ (total)

$\mathrm{Si}+\mathrm{Zn}$ (total)

$\mathrm{Fe}+\mathrm{Cr}+\mathrm{Ni}$ (total)

Any other single impurity (except Am, $\mathrm{Zr}$ )

Total of all impurities (except Am, $\mathrm{Zr}$ )

Total of all impurities (including $\mathrm{Am}, \mathrm{Zr}$ )

Plutonium-240 as a decay product of ${ }^{244} \mathrm{Cm}$ will be present in amounts increasing with time following chemical processing.

\section{Specific Power} $\begin{array}{ll}\text { a. } & 2.84 \mathrm{w} / \mathrm{g} \text { of }{ }^{244} \mathrm{Cm} \text { ( } 100 \%{ }^{244} \mathrm{Cm} \text { isotope) } \\ 2.70 \mathrm{w} / \mathrm{g} \text { of pure curium element (95.08\% }{ }^{244} \mathrm{Cm} \text { isotope) } & 4,5\end{array}$

$2.62 \mathrm{w} / \mathrm{g}$ of curium product ( $97 \%$ chemically pure)

b. Specific power values are based on $81.3 \mathrm{Ci} / \mathrm{g}$ of ${ }^{244} \mathrm{Cm}(100 \%)$ and $34.95 \mathrm{w} / \mathrm{kCi}$ of ${ }^{244} \mathrm{Cm}$.

3. Radiation

a. Alpha particles

\begin{tabular}{|c|c|c|c|c|c|}
\hline Nuclide & $\begin{array}{l}\text { Max E, } \\
\text { Mev }\end{array}$ & $\begin{array}{c}\text { Av E, } \\
\text { Mev }\end{array}$ & $\begin{array}{c}\text { Abundance, } \\
\%\end{array}$ & $\mathrm{w} / \mathrm{kCi}$ & $\begin{array}{l}\text { Particles } \\
\mathrm{w}^{-1} \mathrm{sec}^{-1}\end{array}$ \\
\hline & $\begin{array}{l}5.801 \\
5.759\end{array}$ & $\begin{array}{l}5.801 \\
5.759\end{array}$ & $\begin{array}{l}76.7 \\
23.3\end{array}$ & 34.3 & $\begin{array}{l}0.825 \times 10^{12} \\
0.252 \times 10^{12}\end{array}$ \\
\hline
\end{tabular}

The volume of helium from alpha decay as a function of decay time is given in the following table.

\begin{tabular}{ccc}
\hline \multirow{2}{*}{$\begin{array}{c}\text { Volume of helium, } \\
\mathrm{cm}^{3} \text { of He per } \mathrm{g} \text { of }{ }^{244} \mathrm{Cm}\end{array}$} & Years & Half-lives \\
\hline 6.15 & 1.8 & 0.1 \\
11.8 & 3.6 & 0.2 \\
17.3 & 5.4 & 0.3 \\
22.1 & 7.2 & 0.4 \\
26.9 & 9.1 & 0.5 \\
31.2 & 10.9 & 0.6 \\
35.3 & 12.7 & 0.7 \\
39.1 & 14.5 & 0.8
\end{tabular}


continued

\begin{tabular}{ccc}
\hline \multirow{2}{*}{$\begin{array}{c}\text { Volume of helium, } \\
\mathrm{cm}^{3} \text { of He per } \mathrm{g} \text { of }{ }^{244} \mathrm{Cm}\end{array}$} & \multicolumn{2}{c}{ Time } \\
\cline { 3 - 3 } & Years & Half-lives \\
42.6 & 16.3 & 0.9 \\
45.9 & 18.1 & 1.0 \\
59.3 & 27.1 & 1.5 \\
68.9 & 36.2 & 2.0 \\
80.3 & 54.3 & 3.0 \\
86.1 & 72.4 & 4.0 \\
88.9 & 90.5 & 5.0 \\
91.7 & 181.0 & 10.0 \\
\hline
\end{tabular}

astandard conditions

b. Beta particles

None

c. Gamma

The significant gamma emissions of product-grade ${ }^{244} \mathrm{Cm} \quad 4$ are listed in the following table. The gamma emissions result from the following:

(1) Decay of curium nuclides and of ${ }^{243} \mathrm{Am}$ (based on 0.02 wt $\% 242 \mathrm{Cm}, 0.002$ wt $\%{ }^{243} \mathrm{Cm}, 95.3$ wt $\%$ ${ }^{244} \mathrm{Cm}$, and 0.5 wt $\%{ }^{243} \mathrm{Am}$.

(2) Spontaneous fission of ${ }^{244} \mathrm{Cm}$ and ${ }^{252} \mathrm{Cf}$ (based on a maximum of $4 \times 10^{-5}$ wt $\%{ }^{252} \mathrm{Cf}$ ).

(3) Decay of fission products resulting from the spontaneous fission of ${ }^{244} \mathrm{Cm}$ and ${ }^{252} \mathrm{Cf}$.

(4) Decay of fission products formed in the irradiation process and not removed in the chemical separation procéss.

Significant Gamma Rays of Curium-244 Product

\begin{tabular}{|c|c|c|c|c|c|c|c|c|c|c|}
\hline \multirow{3}{*}{$\begin{array}{l}\text { Energy, } \\
\text { Mev }\end{array}$} & \multicolumn{10}{|c|}{ Abundance, photons $/(\mathrm{sec})\left(w^{244} \mathrm{Cm}\right.$ product $)$} \\
\hline & \multicolumn{4}{|c|}{ From decay of nuclides } & \multicolumn{2}{|c|}{$\begin{array}{c}\text { From spontaneous } \\
\text { fissions }\end{array}$} & \multicolumn{2}{|c|}{$\begin{array}{l}\text { From fission } \\
\text { products of }\end{array}$} & \multirow{2}{*}{$\begin{array}{l}\text { From } \\
\text { impum } \\
\text { rities }\end{array}$} & \multirow[t]{2}{*}{ Total } \\
\hline & ${ }^{242} \mathrm{Cm}$ & ${ }^{243} \mathrm{Cm}$ & ${ }^{244} \mathrm{Cm}$ & $243 \mathrm{Am}$ & ${ }^{244} \mathrm{~cm}$ & $252 \mathrm{Cf}$ & ${ }^{244} \mathrm{Cm}$ & ${ }^{252} \mathrm{Cf}$ & & \\
\hline $0.0-0.5$ & $4.1 \times 10^{6}$ & $3.6 \times 10^{6}$ & $2.5 \times 10^{8}$ & $1.0 \times 10^{7}$ & $4.1 \times 10^{6}$ & $4.9 \times 10^{5}$ & $2.2 \times 10^{6}$ & $1.9 \times 10^{5}$ & $2.2 \times 10^{7}$ & $3.0 \times 10^{8}$ \\
\hline $0.5-1.0$ & $3.0 \times 10^{4}$ & - & $2.2 \times 10^{6}$ & - & $2.6 \times 10^{6}$ & $2.5 \times 10^{5}$ & $6.7 \times 10^{6}$ & $6.0 \times 10^{5}$ & $7.5 \times 10^{6}$ & $2.0 \times 10^{7}$ \\
\hline $1: 0-2.0$ & $9.0 \times 10^{2}$ & - & - & - & $1.9 \times 10^{6}$ & $1.8 \times 10^{5}$ & $1.5 \times 10^{6}$ & $1.3 \times 10^{5}$ & $1.1 \times 10^{6}$ & $4.9 \times 10^{6}$ \\
\hline $2.0-3.0$ & - & - & - & - & $6.0 \times 10^{5}$ & $4.9 \times 10^{4}$ & $6.0 \times 10^{5}$ & $5.2 \times 10^{2}$ & $3.7 \times 10^{5}$ & $1.6 \times 10^{6}$ \\
\hline $3.0-4.0$ & - & - & - & - & $1.8 \times 10^{5}$ & $1.3 \times 10^{4}$ & - & - & - & $1.9 \times 10^{5}$ \\
\hline $4.0-5.0$ & - & - & - & - & $6.0 \times 10^{4}$ & $3.7 \times 10^{3}$ & - & - & - & $6.4 \times 10^{4}$ \\
\hline $5.0-6.0$ & - & - & - & - & $3.3 \times 10^{4}$ & $1.0 \times 10^{3}$ & - & - & - & $3.3 \times 10^{4}$ \\
\hline $6.0-7.0$ & - & - & - & - & $5.6 \times 10^{3}$ & $1.5 \times 10^{2}$ & - & - & - & $5.6 \times 10^{3}$ \\
\hline
\end{tabular}

d. Bremsitrahlung

None 
e. Neutrons

$4.19 \times 10^{6}$ neutrons $\mathrm{sec}^{-1} \mathrm{w}^{-1}$ of ${ }^{244} \mathrm{Cm}$ from spontaneous fission (half-life for spontaneous fission is $\left.1.4 \times 10^{7} \mathrm{y}\right)$.

$1.51 \times 10^{5}$ neutrons $\mathrm{sec}^{-1} \mathrm{w}^{-1}$ of ${ }^{244} \mathrm{~cm}$ from $(\alpha, n)$ reaction on oxygen in $\mathrm{Cm}_{2} \mathrm{O}_{3}$.

$3.5 \times 10^{5}$ neutrons $\sec ^{-1} \mathrm{w}^{-1}$ of ${ }^{244} \mathrm{Cm}$ from estimated maximum of ${ }^{252} \mathrm{Cf}$ content of $4 \times 10^{-5}$ wt $\%$.

The energy distribution of spontaneous fission neutrons 4 from ${ }^{244} \mathrm{Cm}$ is given in the following table.

\begin{tabular}{|c|c|}
\hline $\begin{array}{l}\text { Energy, } \\
\text { Mev }\end{array}$ & $\begin{array}{l}\text { Abundance, } \\
\text { neutrons } \sec ^{-1} \mathrm{w}^{-1} \text { of }{ }^{244} \mathrm{Cm}\end{array}$ \\
\hline $\begin{array}{l}0.3-0.4 \\
0.4-0.6 \\
0.6-0.8 \\
0.8-1.0\end{array}$ & $\begin{array}{l}1.51 \times 10^{5} \\
3.13 \times 10^{5} \\
3.20 \times 10^{5} \\
2.77 \times 10^{5}\end{array}$ \\
\hline $\begin{array}{l}1.0-1.2 \\
1.2-1.4 \\
1.4-1.6 \\
1.6-1.8 \\
1.8-2.0\end{array}$ & $\begin{array}{l}2.84 \times 10^{5} \\
2.80 \times 10^{5} \\
2.44 \times 10^{5} \\
2.19 \times 10^{5} \\
1.98 \times 10^{5}\end{array}$ \\
\hline $\begin{array}{l}2.0-2.2 \\
2.2-2.4 \\
2.4-2.6 \\
2.6-2.8 \\
2.8-3.0\end{array}$ & $\begin{array}{l}1.80 \times 10^{5} \\
1.65 \times 10^{5} \\
1.58 \times 10^{5} \\
1.30 \times 10^{5} \\
1.08 \times 10^{5}\end{array}$ \\
\hline $\begin{array}{l}3.0-3.2 \\
3.2-3.4 \\
3.4-3.6 \\
3.6-3.8 \\
3.8-4.0\end{array}$ & $\begin{array}{l}1.01 \times 10^{5} \\
0.97 \times 10^{5} \\
0.93 \times 10^{5} \\
0.75 \times 10^{5} \\
0.79 \times 10^{5}\end{array}$ \\
\hline $\begin{array}{l}4.0-4.4 \\
4.4-4.8 \\
4.8-5.2 \\
5.2-5.6 \\
5.6-6.0\end{array}$ & $\begin{array}{l}1.04 \times 10^{5} \\
0.86 \times 10^{5} \\
0.65 \times 10^{5} \\
0.50 \times 10^{5} \\
0.40 \times 10^{5}\end{array}$ \\
\hline $\begin{array}{l}6.0-6.4 \\
6.4-6.8 \\
6.8-7.2 \\
7.2-7.6 \\
7.6-8.0\end{array}$ & $\begin{array}{l}2.95 \times 10^{4} \\
2.12 \times 10^{4} \\
1.47 \times 10^{4} \\
1.12 \times 10^{4} \\
0.90 \times 10^{4}\end{array}$ \\
\hline $\begin{array}{l}8.0-8.8 \\
8.8-9.6 \\
9.6-10.4 \\
10.4-11.2 \\
11.2-12.8\end{array}$ & $\begin{array}{l}1.01 \times 10^{4} \\
2.95 \times 10^{3} \\
3.1 \times 10^{3} \\
2.05 \times 10^{3} \\
1.40 \times 10^{3}\end{array}$ \\
\hline
\end{tabular}


The energy distribution of neutrons occurring as a result of the collision of fast alpha particles from ${ }^{244} \mathrm{Cm}$ decay with oxygen atoms in $\mathrm{Cm}_{2} \mathrm{O}_{3}$ is given in the following table.

$\begin{array}{cc}\begin{array}{c}\text { Neutrons from }(\alpha, \mathrm{n}) \\ \text { Energy, } \\ \text { Mev }\end{array} & \begin{array}{c}\text { Abundance, } \\ \text { neutrons } \mathrm{sec}^{-1} \mathrm{w}^{-1} \text { of }{ }^{244} \mathrm{Cm}\end{array} \\ 0.2 & 1.62 \times 10^{2} \\ 0.4 & 0.68 \times 10^{3} \\ 0.6 & 0.83 \times 10^{3} \\ 0.8 & 1.69 \times 10^{3} \\ 1.0 & 2.70 \times 10^{3} \\ 1.2 & 0.43 \times 10^{4} \\ 1.4 & 0.61 \times 10^{4} \\ 1.6 & 0.83 \times 10^{4} \\ 1.8 & 1.01 \times 10^{4} \\ 2.0 & 1.19 \times 10^{4} \\ 2.2 & 1.33 \times 10^{4} \\ 2.4 & 1.40 \times 10^{4} \\ 2.6 & 1.40 \times 10^{4} \\ 2.8 & 1.37 \times 10^{4} \\ 3.0 & 1.22 \times 10^{4} \\ 3.2 & 1.01 \times 10^{4} \\ 3.4 & 0.79 \times 10^{4} \\ 3.6 & 0.50 \times 10^{4} \\ 3.8 & 3.02 \times 10^{3} \\ 4.0 & 2.01 \times 10^{3} \\ 4.2 & 1.37 \times 10^{3} \\ 4.4 & 0.86 \times 10^{3} \\ 4.6 & 0.72 \times 10^{2} \\ & \end{array}$

4. Critical Mass

The critical mass of unreflected and reflected spheres of

${ }^{244} \mathrm{Cm}$ and ${ }^{244} \mathrm{Cm}_{2} \mathrm{O}_{3}$ have been calculated by $\mathrm{C}$. W. Craven, $\mathrm{Jr}$, at ORNL using the cross-section data available as of November 1965. The results, shown in the following table, agree within 10\% of the results obtained in the replacement experiment at Los Alamos. The critical mass equations used are

$$
\begin{aligned}
\mathrm{Cm}: \mathrm{M}_{\mathrm{c}} & =2450 / \rho^{2} \quad(\mathrm{~kg}) \\
\mathrm{Cm}_{2} \mathrm{O}_{3}: \mathrm{M}_{\mathrm{C}} & =2370 / \rho^{2} \quad(\mathrm{~kg})
\end{aligned}
$$


Calculated Critical Mass of ${ }^{244} \mathrm{Cm}$ and ${ }^{244} \mathrm{Cm}_{2} \mathrm{O}_{3}$

\begin{tabular}{|c|c|c|c|c|c|}
\hline \multicolumn{2}{|c|}{ Core } & \multicolumn{2}{|c|}{ Reflector } & \multirow[b]{2}{*}{$\begin{array}{l}\text { Critical } \\
\text { mass, } \mathrm{kg}\end{array}$} & \multirow{2}{*}{$\begin{array}{c}\text { Critical } \\
\text { radius, } \\
\mathrm{cm}\end{array}$} \\
\hline Mixture & $\begin{array}{c}\text { Density, } \\
\mathrm{g} / \mathrm{cm}^{3}\end{array}$ & Mixture & $\begin{array}{c}\text { Thickness, } \\
\mathrm{cm}\end{array}$ & & \\
\hline $\mathrm{Cm}^{\mathrm{a}}$ & 14.0 & Bare & - & 12.5 & 5.97 \\
\hline $\mathrm{Cm}_{2} \mathrm{O}_{3}{ }^{\mathrm{a}}$ & 10.60 & Bare & - & $21 \cdot 1$ & 7.8031 \\
\hline $\mathrm{Cm}_{2} \mathrm{O}_{3}$ & 9.01 & Bare & - & 29.2 & 9.1803 \\
\hline $\mathrm{Cm}_{2} \mathrm{O}_{3}$ & 10.60 & $\mathrm{Au}-\mathrm{H}_{2} \mathrm{O}$ & $4.0-15.0$ & $11 \cdot 9$ & 6.4540 \\
\hline $\mathrm{Cm}_{2} \mathrm{O}_{3}$ & 10.60 & $\mathrm{Au}-\mathrm{H}_{2} \mathrm{O}$ & $2 \cdot 0-7.5$ & 13.5 & 6.7188 \\
\hline $\mathrm{Cm}_{2} \mathrm{O}_{3}$ & 10.60 & $\mathrm{Au}-\mathrm{H}_{2} \mathrm{O}$ & $0.5-2.0$ & 16.5 & $7 \cdot 1966$ \\
\hline
\end{tabular}

assumed composition: 98.07 wt $\%{ }^{244} \mathrm{Cm}$ and 1.93 wt $\%{ }^{241} \mathrm{Pu}$.

5. Compatibility with Materials of Containment

6. Thermophysical Properties

a. Density

$13.51 \mathrm{~g} / \mathrm{cm}^{3}$ of metal

b. Coefficient of thermal expansion

$$
\begin{aligned}
& \alpha_{a}=7.5 \times 10^{-6} /{ }^{\circ} \mathrm{C} \\
& \alpha_{c}=6.2 \times 10^{-6} /{ }^{\circ} \mathrm{C}
\end{aligned}
$$

c. Specific heat and enthalpy

(1) Specific heat

$$
0.0270 \mathrm{cal} \mathrm{g}^{-1}{ }^{\circ} \mathrm{C}^{-1}
$$

(2) Enthalpy in cal $/ \mathrm{mole}$

$$
\begin{aligned}
\mathrm{H}_{\mathrm{t}}-\mathrm{H}_{\mathrm{O}}=6.48 & +3.53 \times 10^{-3} \mathrm{t}^{2} \\
& +1.49 \times 10^{-6} \mathrm{t}^{3}
\end{aligned}
$$

(Na temperature is $0-400^{\circ} \mathrm{C}$ and $t$ is in ${ }^{\circ} \mathrm{C}$ )

d. Temperatures of phase transformations

(1) Melting point

$$
1340 \pm 40^{\circ} \mathrm{C}
$$

$1350 \pm 60^{\circ} \mathrm{C}$

(2) Boiling point

$3525 \pm 130^{\circ} \mathrm{C}$ 
e. Latent heats of phase transformations

$\triangle \mathrm{H}$ fusion $\quad 3.2 \mathrm{kcal} / \mathrm{mole}$ (Richard's rule)

f. Vapor pressure

$\log _{10} P=4.74 \pm 0.37-[(18,060 \pm 590) / T]$

( $T$ is in ${ }^{\circ} \mathrm{K}$ and $\mathrm{P}$ is in atm)

g. Thermal conductivity

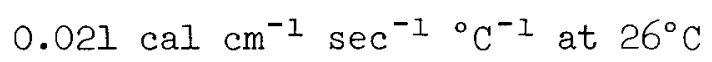

h. Thermal diffusivity

$0.575 \mathrm{~cm}^{2} / \mathrm{sec}$ at $26^{\circ} \mathrm{C}$

This value was calculated by dividing the product of the specific heat and density into the thermal conductivity.

i. Viscosity

2.5 centipoises at $1340^{\circ} \mathrm{C}$

j. Surface tension

$500 \mathrm{dyn} / \mathrm{cm}$

k. Total hemispherical emittance

0.37 at $89^{\circ} \mathrm{C}$

1. Spectral emissivity

0.55

A higher value of 0.9 can be assumed if the metal

surface is oxidized or if impurities are present.

m. Crystallography

Double hexagonal close packed

$\mathrm{a}=3.496 \pm 0.003 \AA \quad c=11.331 \pm 0.005 \AA$

n. Solubilities

Reacts strongly with water

o. Diffusion rates

\section{Mechanical Properties}

a. Hardness

Vicker's $\quad 97.7$ 
CURIUM-244 METAL

b. Crush strength

$7741 \mathrm{~kg} / \mathrm{cm}^{2}$

8. Chemical Properties

a. Heat and free energy of formation, entropy
(1) Heat of formation
Zero - by definition of standard state
(2) Free energy of formation
Zero - by definition of standard state
(3) Entropy

$$
\mathrm{S}_{298}^{\circ}=18 \mathrm{cal}{ }^{\circ} \mathrm{C}^{-1} \mathrm{~mole} \mathrm{e}^{-1}
$$

b. Chemical reactions and reaction rates

$\begin{array}{ll}\text { (1) Oxygen at room temperature - slow } & 11 \\ \text { (2) Oxygen at elevated temperature - fast } & 11 \\ \text { (3) Nitrogen at room temperature - very slow } & 25 \\ \text { (4) Nitrogen at elevated temperature - slow } & 25 \\ \text { (5) Water at room temperature - fast } & 23 \\ \text { (6) Hydrogen at room temperature - slow } & 23 \\ \text { (7) Hydrogen at elevated temperature - fast } & 23\end{array}$

9. Biological Tolerances

Maximum permissible body burdens and maximum permissible 26 concentrations of ${ }^{244} \mathrm{Cm}$ in air and water are shown in

the following table.

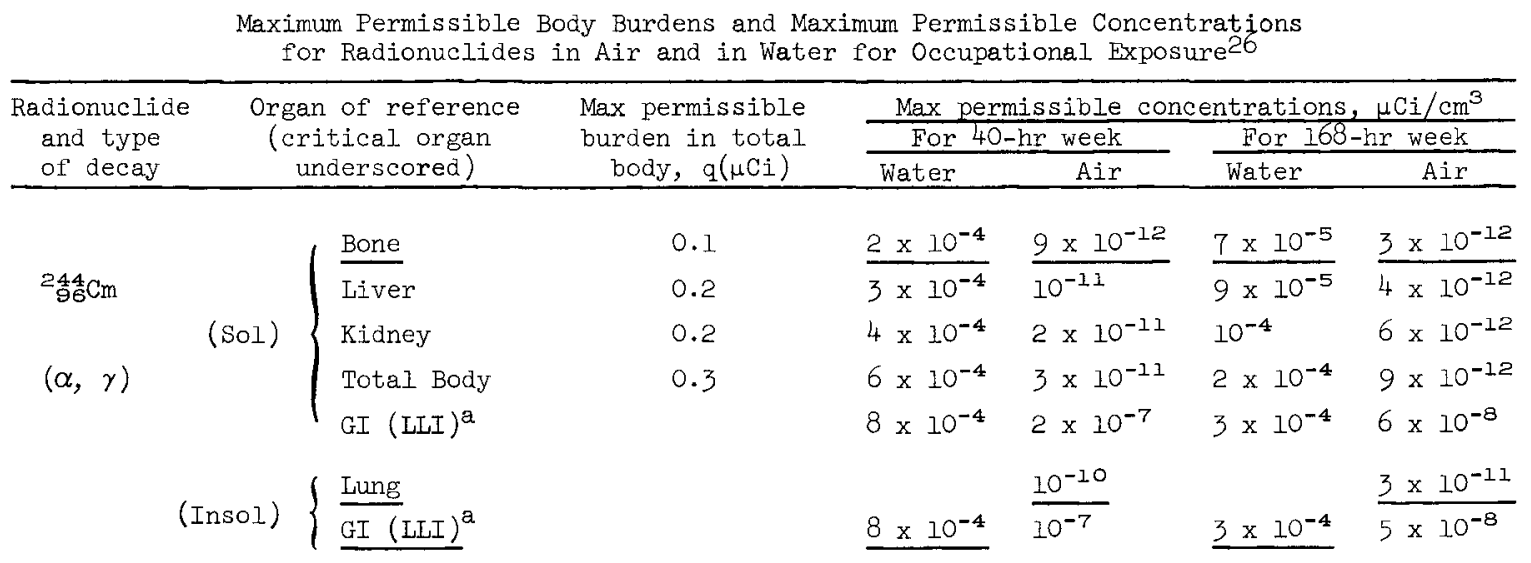

The abbreviations GI and LII refer to the gastrointestinal tract and lower large intestine, respectively. 


\section{Shielding Data}

Gamma dose rates with water, iron, lead, and uranium shielding are given in Figs. $1-5$ for ${ }^{244} \mathrm{Cm}$ power sources of 100, 200, 500, 1000, 2000, 5000, 10,000, and 20,000 w. Neutron dose rates with water shielding are given in Fig. 6. Neutron dose rates on shielding with $\mathrm{Be}, \mathrm{CH}$, $\mathrm{CH}_{2}$, or $\mathrm{LiH}$ can be estimated by using Fig. 6 in conjunction with Fig. 7 .

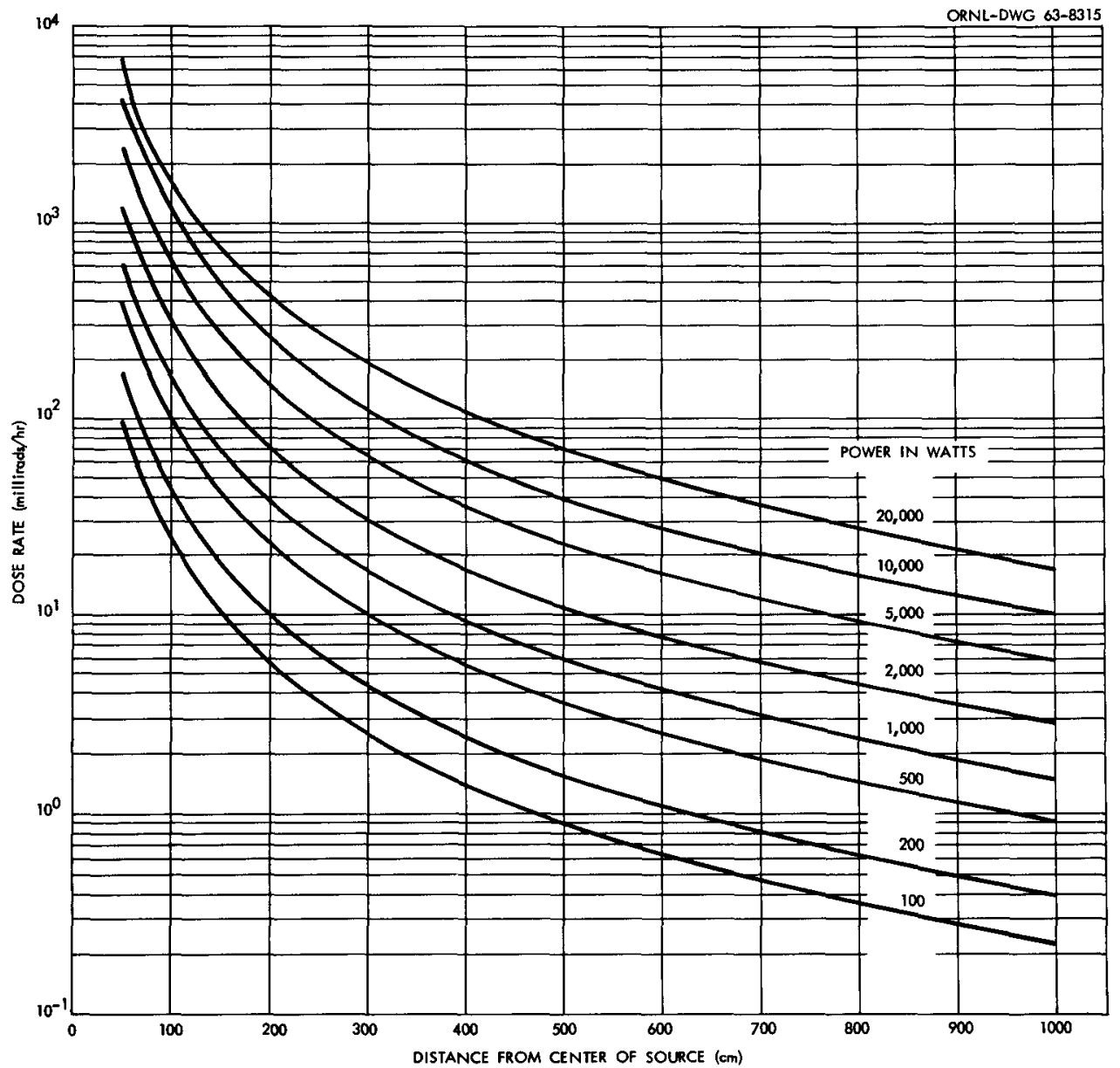

Fig. I. Gamma Dose Rates from Unshielded Isotopic Power Sources of Curium-244 as a Function of Distance from Center of Source. 


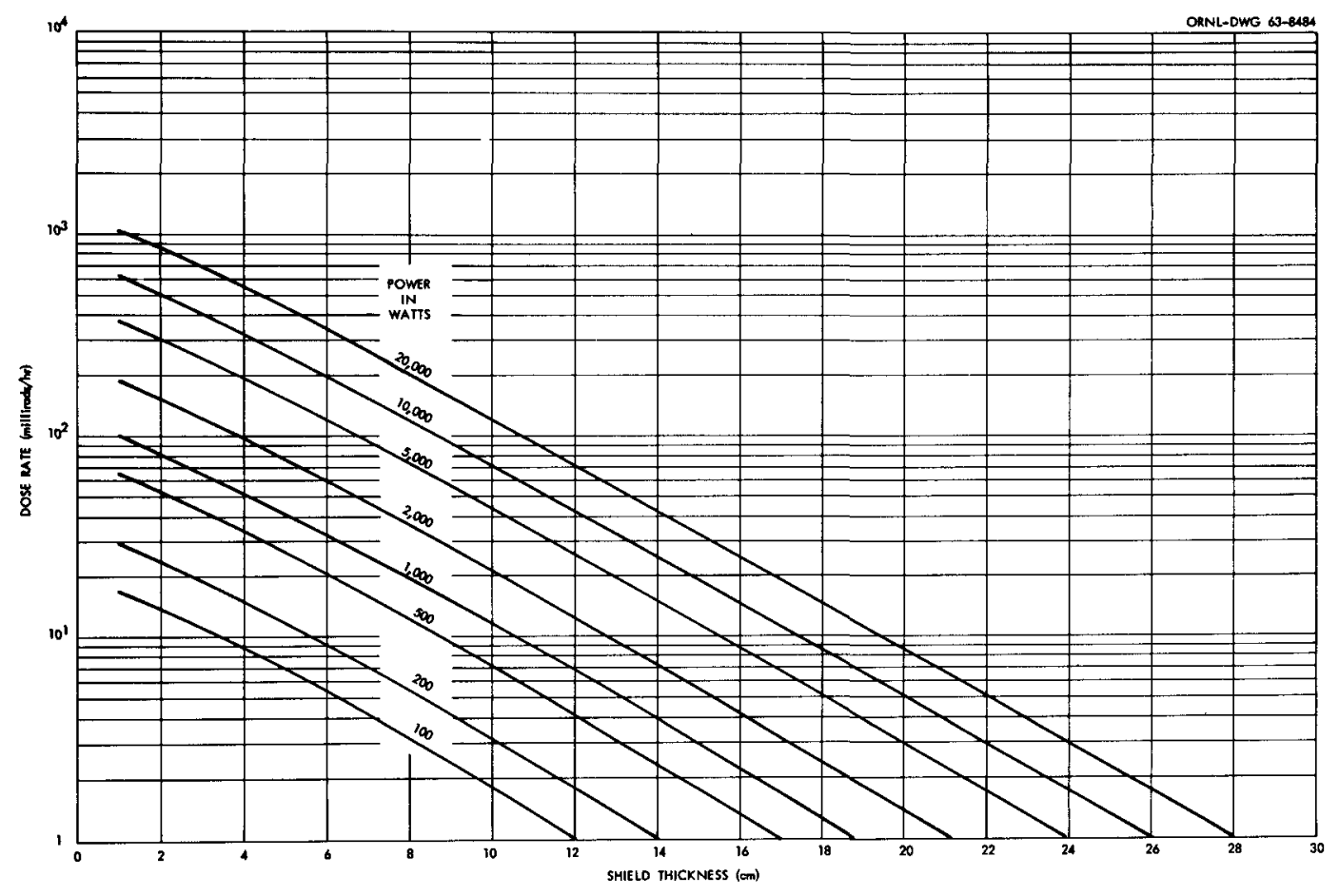

Fig. 2. Gamma Dose Rates from Iron-Shielded Isotopic Power Sources of Curium-244. Center of source to dose point separation distance is $100 \mathrm{~cm}$.

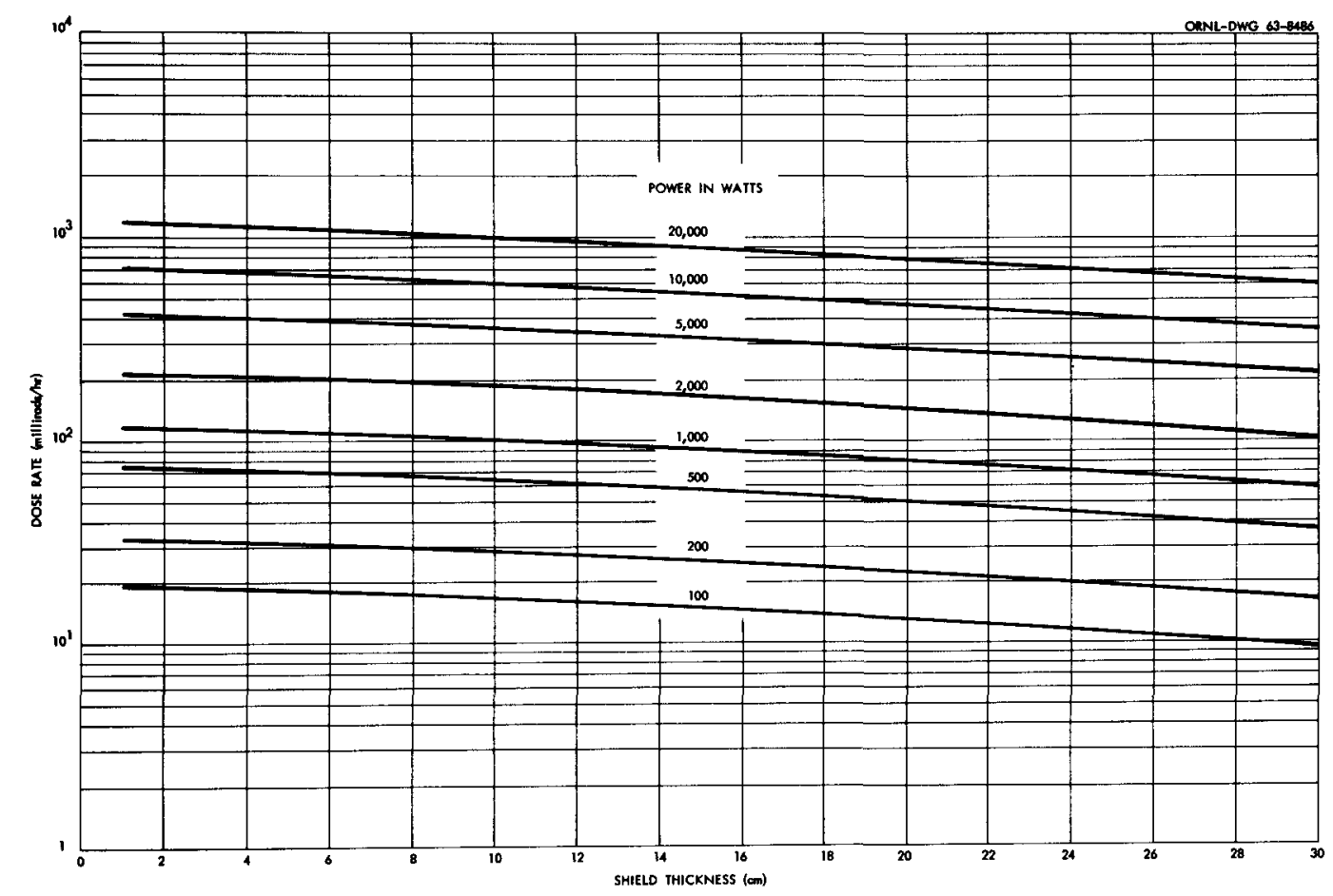

Fig. 3. Gamma Dose Rates from Water-Shielded Isotopic Power Sources of Curium-244. Center of source to dose point separation distance is $100 \mathrm{~cm}$. 


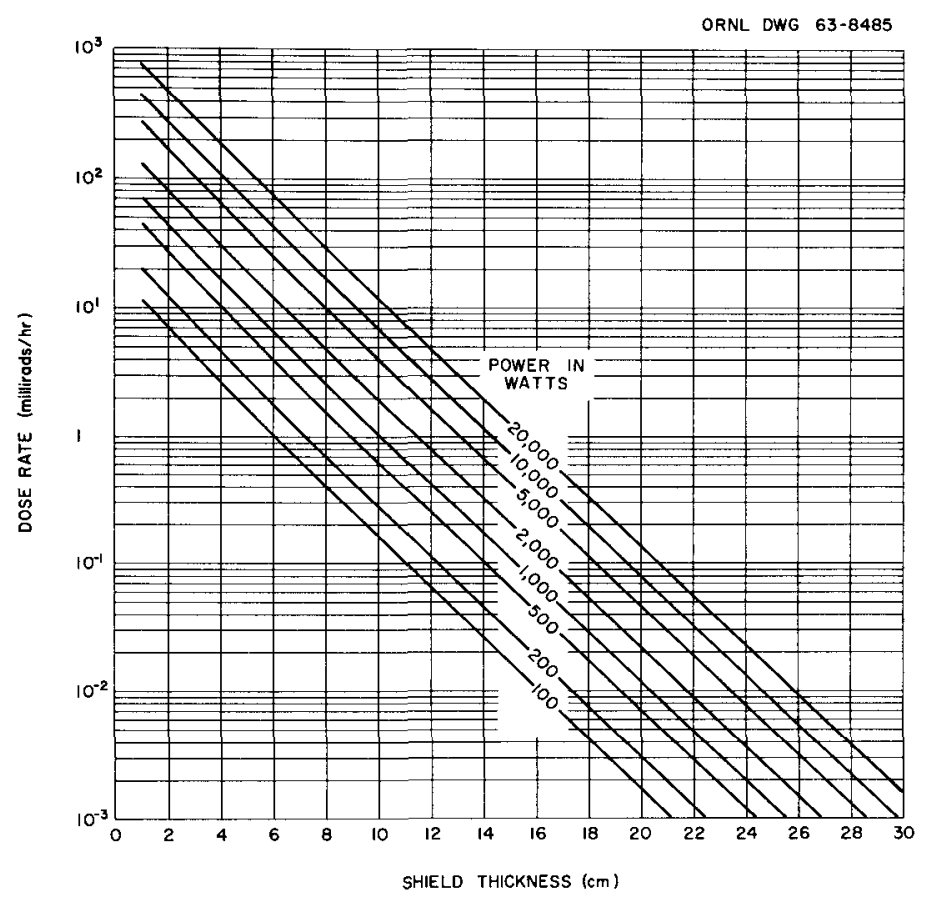

Fig. 4. Gamma Dose Rates from

Lead-Shielded Isotopic Power Sources of

Curium-244. Center of source to dose point separation distance is $100 \mathrm{~cm}$.

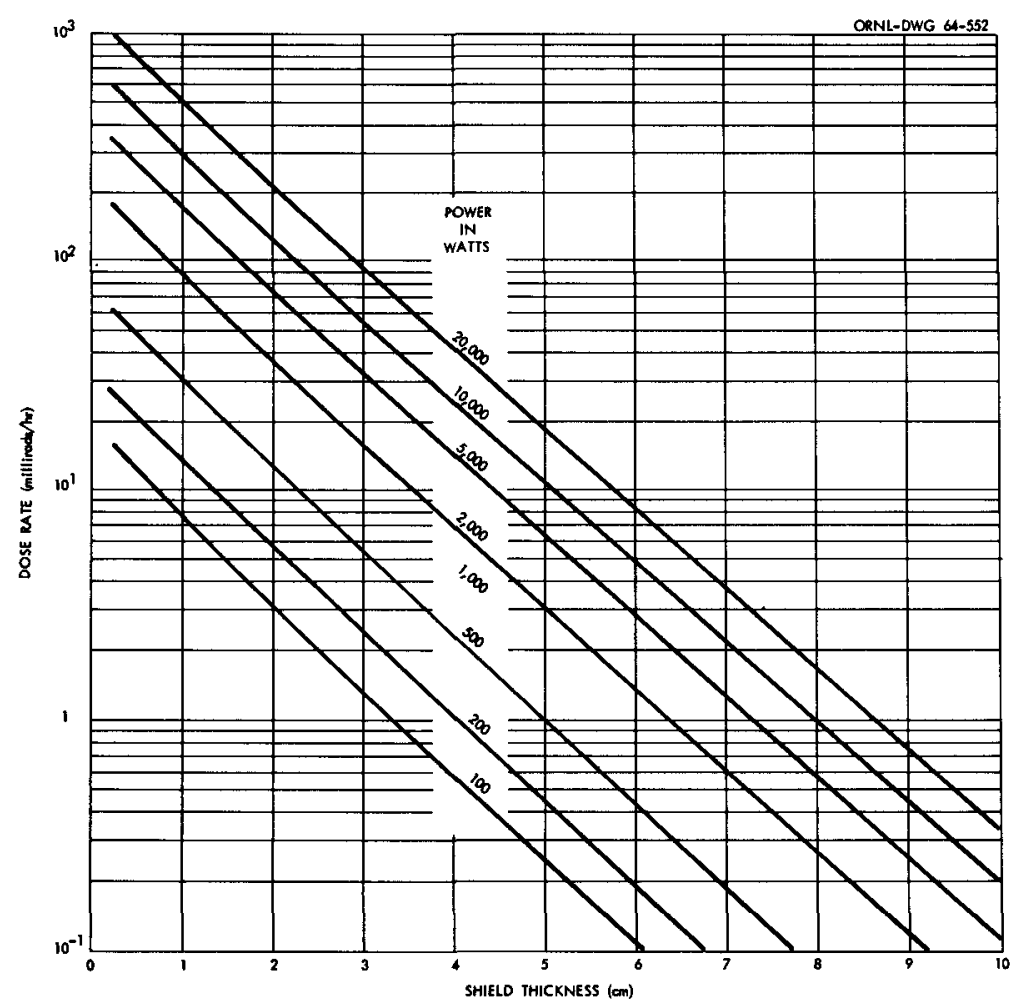

Fig. 5. Gamma Dose Rates from UraniumShielded Isotopic Power Sources of Curium-244. Center of source to dose point separation distance is $100 \mathrm{~cm}$. 


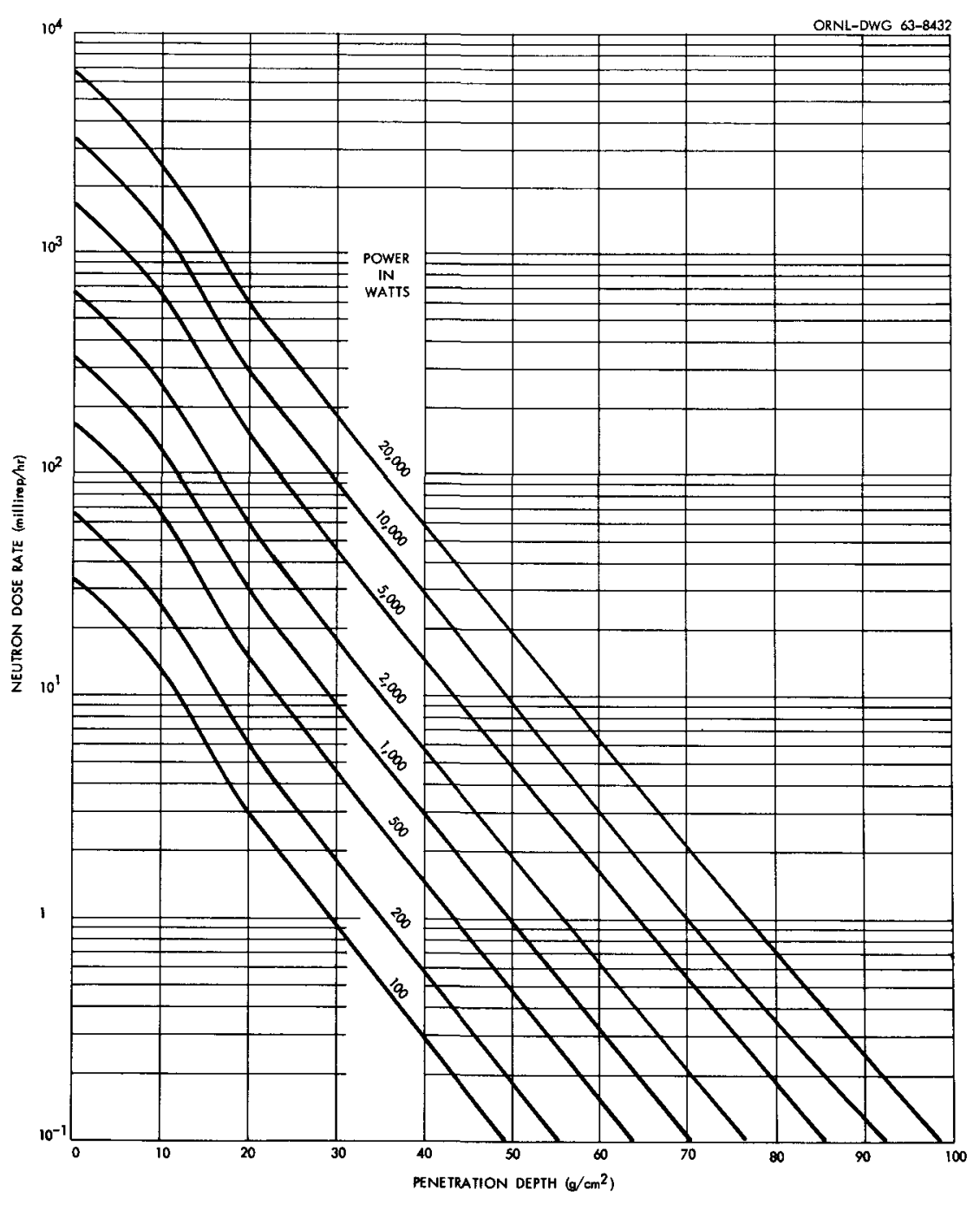

Fig. 6. Neutron Dose Rates from Water-Shielded Isotopic Power Sources of Curium-244 as a Function of Penetration Depth of Shielding Material. Center of source to dose point separation distance is $100 \mathrm{~cm}$.

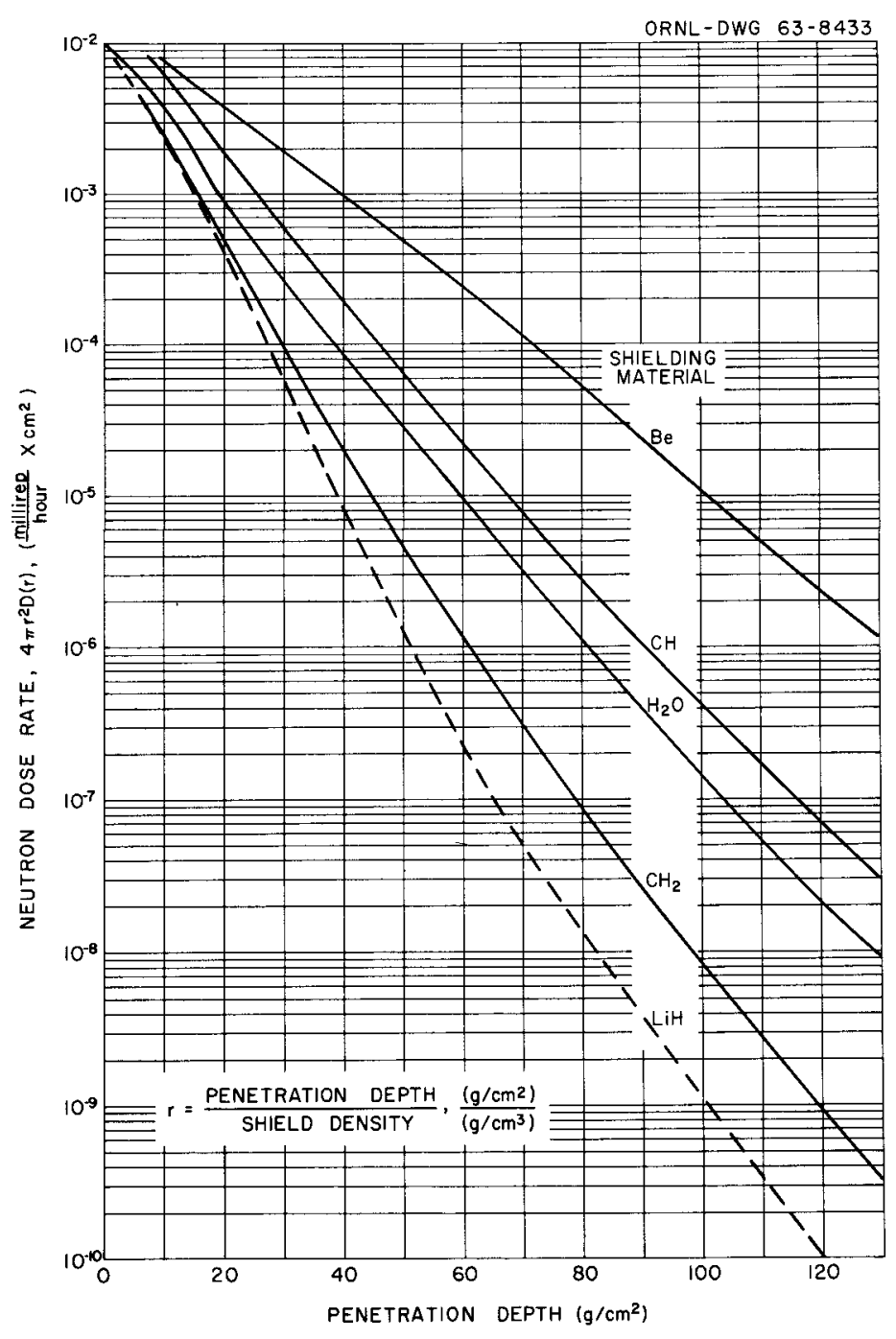

Fig. 7. Fast Neutron Dose Rate

(Multiplied by $4 \pi r^{2}$ ) in Various Materials as a Function of Penetration Depth from a Unit Point Isotropic Fission Source. 
B. CURIUM SESQUIOXIDE $\left(\mathrm{Cm}_{2} \mathrm{O}_{3}\right)$

1. Composition

a. Radionuclidic abundance

See Section I.A.I.a.

b. Radiochemical purity

See Section I.A.I.b.

c. Chemical purity

See Section I.A.I.C.

d. Phase composition of various curium oxides

$$
\begin{array}{ll}
\mathrm{CmO}_{2.00} & \mathrm{CmO}_{1.52-1} .62(\mathrm{C} \text {-type }) \\
\mathrm{CmO}_{1.83}\left(\mathrm{Cm}_{6} \mathrm{O}_{11}\right) & \mathrm{CmO}_{1} .50(\mathrm{~B}-\text { and } \mathrm{A} \text {-type }) \\
\mathrm{CmO}_{1.71}\left(\mathrm{Cm}_{7} \mathrm{O}_{12}\right) &
\end{array}
$$

2. Specific Power
a. $2.46 \mathrm{w} / \mathrm{g}$ of $100 \%$ pure $\mathrm{Cm}_{2} \mathrm{O}_{3}\left(86.5 \%{ }^{244} \mathrm{Cm}\right.$ isotope)
$2.38 \mathrm{w} / \mathrm{g}$ of $97 \%$ pure $\mathrm{Cm}_{2} \mathrm{O}_{3}\left(83.9 \%{ }^{244} \mathrm{Cm}\right.$ isotope $)$
$4,5,6$
b. Specific power values are based on $81.3 \mathrm{Ci} / \mathrm{g}$ of ${ }^{244} \mathrm{Cm}(100 \%)$ isotope and $34.95 \mathrm{w} / \mathrm{kCi}$ of ${ }^{244} \mathrm{Cm}$.

3. Radiation

The radiation is given under section I.A.3.

4. Critical Mass

See Section I.A.4.

5. Compatibility with Materials of Containment

See ORNL-4359, Compatibility Data Sheets for Cerium-144, Cesium-137, Curium, and Strontium-90 (classified).

6. Thermophysical Properties

a. Density (calculated from lattice parameters)

$$
\begin{array}{lll}
\text { C-type (bcc) } & 10.70 \mathrm{~g} / \mathrm{cm}^{3} \text { at room temperature } & 29 \\
\text { B-type (monoclinic) } & 11.67 \mathrm{~g} / \mathrm{cm}^{3} \text { at room temperature } & 29 \\
\text { A-type (hex) } & 11.4 \mathrm{~g} / \mathrm{cm}^{3} \text { at } 1640^{\circ} \mathrm{C} & 29 \\
& 11.1 \mathrm{~g} / \mathrm{cm}^{3} \text { at } 1750^{\circ} \mathrm{C} & \\
& 11.0 \mathrm{~g} / \mathrm{cm}^{3} \text { at } 1910^{\circ} \mathrm{C}
\end{array}
$$


b. Coefficient of thermal expansion

B-type (monoclinic) $\mathrm{Cm}_{2} \mathrm{O}_{3}$

$0.60 \%$ over $25-680^{\circ} \mathrm{C}$

$0.85 \%$ over $25-940^{\circ} \mathrm{C}$

$1.4 \%$ over $25-1300^{\circ} \mathrm{C}$

c. Specific heat and enthalpy

(1) Specific heat in cal $\mathrm{g}^{-1}{ }^{\circ} \mathrm{C}^{-1}$

$$
3.7 \times 10^{-2}+2.91 \times 10^{-5} \mathrm{~T}\left({ }^{\circ} \mathrm{K}\right)
$$

(2) Enthalpy

d. Temperatures of phase transformations

(1) Phase transitions

C-type $\mathrm{Cm}_{2} \mathrm{O}_{3}$ (bcc) transforms irreversibly to $\mathrm{B}$-type $\mathrm{Cm}_{2} \mathrm{O}_{3}$ (monoclinic) between $800-1300^{\circ} \mathrm{C}$ depending on degree of crystallinity of cubic $29,31,32$, form.

$\mathrm{B}$-type $\mathrm{Cm}_{2} \mathrm{O}_{3}$ (monoclinic) transforms reversibly to A-type $\mathrm{Cm}_{2} \mathrm{O}_{3}$ (hex) at $1600^{\circ} \mathrm{C}$.

(2) Melting point

$2265 \pm 20^{\circ} \mathrm{C}$

$2180 \pm 20^{\circ} \mathrm{C}$ (production oxide)

$2230 \pm 25^{\circ} \mathrm{C}$ (SRL production, Batch 1 )

16,36

16,36

(3) Boiling point

$3700 \pm 200^{\circ} \mathrm{C}$

(4) Thermogravimetric analytical work on the decomposition of $\mathrm{CmO}_{2}$ to $\mathrm{Cm}_{2} \mathrm{O}_{3}$ at SRI confirmed previous work at ORNL and indicated some variations from earlier SRI results. Stable oxide phases and temperature ranges of stability in various atmospheres are:

\begin{tabular}{|c|c|c|c|c|}
\hline \multirow[b]{2}{*}{ Phase } & \multirow[b]{2}{*}{ Composition } & \multicolumn{3}{|c|}{$\begin{array}{l}\text { Range of stability in } \\
\text { indicated atmosphere, }{ }^{\circ} \mathrm{C}\end{array}$} \\
\hline & & Oxygen & Helium & $\begin{array}{l}4 \% \mathrm{H}_{2}- \\
96 \% \mathrm{He} \\
\end{array}$ \\
\hline $\mathrm{CmO}_{2}$ & $\mathrm{CmO}_{2} \cdot 0$ & $<400$ & $<400$ & $<250$ \\
\hline $\mathrm{Cm}_{6} \mathrm{O}_{11}$ & $\mathrm{CmO}_{1.83}$ & $440-450$ & Unstable & Unstable \\
\hline $\mathrm{Cm}_{7} \mathrm{O}_{12}$ & $\mathrm{CmO}_{1} \cdot 71$ & $460-720$ & $450-520$ & Unstable \\
\hline $\mathrm{Cm}_{2} \mathrm{O}_{3}$ & & & & \\
\hline C-type & $\mathrm{CmO}_{1} \cdot 62-1.52$ & $750-870^{a}$ & $600-900$ & $530-750$ \\
\hline B-type & $\mathrm{CmO}_{1} .50$ & $>850$ & $>950$ & $>850$ \\
\hline
\end{tabular}

a Heating terminated at $870^{\circ} \mathrm{C}$. 
e. Latent heats of phase transformations

$\triangle H$ fusion $29 \mathrm{kcal} / \mathrm{mole}$ (Richard's rule) $\Delta H^{\circ}$ vaporization $133.0 \pm 2.7 \mathrm{kcal} / \mathrm{mole}$ of gas between 1600 and $2250^{\circ} \mathrm{C}$

f. Vapor pressure

$\log _{10} P_{E}(\mathrm{~atm})=7.32( \pm 0.26)-\frac{29,050( \pm 590)}{\mathrm{T}\left({ }^{\circ} \mathrm{K}\right)} \quad 32,35,37$

at $1800-2600^{\circ} \mathrm{K}$, where $\mathrm{P}_{\mathrm{E}}$ is an artificial pressure

of $\mathrm{Cm}_{2} \mathrm{O}_{3}(\mathrm{~g})$. The vapor species in the vaporization reaction are unknown. $\mathrm{P}_{\mathrm{E}}$ is related to the actual vapor pressure by a proportionality constant, $k$, given as follows for vaporization to other gaseous species:

$$
\begin{aligned}
& \mathrm{k}=1.415 \text { for } \mathrm{CmO}(\mathrm{g})+\mathrm{CmO}_{2}(\mathrm{~g}) \\
& \mathrm{k}=1.567 \text { for } \mathrm{CmO}(\mathrm{g})+\mathrm{O}(\mathrm{g}) \\
& \mathrm{k}=1.869 \text { for } \mathrm{Cm}(\mathrm{g})+\mathrm{O}(\mathrm{g}) \\
& \mathrm{k}=1.414 \text { for } \mathrm{Cm}(\mathrm{g})+\mathrm{CmO}_{2}(\mathrm{~g})
\end{aligned}
$$

g. Thermal conductivity

Thermal conductivity, Molar heat capacity, Temp, cal $\mathrm{cm}^{-1} \mathrm{sec}^{-1}{ }^{\circ} \mathrm{C}^{-1}$

cal ${ }^{\circ} \mathrm{C}^{-1}$ mole $\mathrm{e}^{-1}$

$$
\begin{array}{r}
{ }^{\circ} \mathrm{C} \\
\hline 27 \\
127 \\
327 \\
527 \\
727 \\
927 \\
1127 \\
1327 \\
1427
\end{array}
$$$$
0.00347
$$$$
0.00378
$$$$
31.50
$$$$
35.00
$$$$
0.00389
$$$$
38.32
$$$$
40.26
$$$$
0.00399
$$$$
41.80
$$$$
0.00393
$$$$
0.00393
$$$$
43.06
$$$$
44.02
$$$$
44.80
$$$$
0.00384
$$$$
45 \cdot 14
$$

These values were calculated from the thermal diffusivities of Chikalla. ${ }^{38}$ The density of the hot-pressed pellet was assumed to remain constant at $11.24 \mathrm{~g} / \mathrm{cm}^{3}$. Values of the molar heat capacities assumed for ${ }^{244} \mathrm{Cm}$ are those of $\mathrm{Pu}_{2} \mathrm{O}_{3}$.

h. Thermal diffusivity

Thermal diffusivity,

\begin{tabular}{l}
$\mathrm{cm}^{2} / \mathrm{sec}$ \\
\hline 0.0053 \\
0.0052 \\
0.0049 \\
0.0047 \\
0.0046 \\
0.0044 \\
0.0043 \\
0.0042 \\
0.0041
\end{tabular}

Temperature,

\begin{tabular}{r}
${ }^{\circ} \mathrm{C}$ \\
\hline 27 \\
127 \\
327 \\
527 \\
727 \\
927 \\
1127 \\
1327 \\
1427
\end{tabular}


h. Thermal diffusivity (continued)

Preliminary data on a hot-pressed $\left(30 \mathrm{~min}\right.$ at $1380^{\circ} \mathrm{C}$ ) $\mathrm{Cm}_{2} \mathrm{O}_{3}$ pellet having a density of $11.24 \mathrm{~g} / \mathrm{cm}^{3}$.

i. Viscosity

j. Surface tension

k. Total hemispherical emittance

1. Spectral emissivity

0.20 to 0.57

The precise value is a function of the roughness of the material surface, the presence of impurities, and the effects of radiation.

m. Crystallography

Body-centered cubic, C-type rare-earth oxide structure with variable lattice parameter, produced by reducing $\mathrm{CmO}_{2}$.

$a=10.922 \pm 0.001\left(\mathrm{CmO}_{1.62}\right)$ to $10.997 \pm 0.003\left(\mathrm{CmO}_{1} .52\right)$ at room temperature

Hexagonal, H-type rare-earth oxide structure,

obtained by irreversible transformation or reaction of $\mathrm{B}$-type $\mathrm{Cm}_{2} \mathrm{O}_{3}$ on noble metals on heating at $1500^{\circ} \mathrm{C}$.

$a=3.863 \pm 0.01 \AA_{0}$ at $1750^{\circ} \mathrm{C}$ on Ir

$\mathrm{c}=6.174 \pm 0.001 \mathrm{~A}$ at $1750^{\circ} \mathrm{C}$ on $\operatorname{Ir}$

Cubic with superstructure, related to bcc structure of $\mathrm{C}$-type $\mathrm{Cm}_{2} \mathrm{O}_{3}$, possibly $\mathrm{CmO}_{1} .72$, obtained by heating $\mathrm{CmO}_{2}$ between 470 and $700^{\circ} \mathrm{C}$ in oxygen ( $1 \mathrm{~atm}$ ).

$a=5.450 \pm 0.001 \AA$ at room temperature after $470^{\circ} \mathrm{C}$ in $\mathrm{O}_{2}$ $a=5.461 \pm 0.001 \AA$ at room temperature after $700^{\circ} \mathrm{C}$ in $\mathrm{O}_{2}$

Cubic, related to ficc structure of $\mathrm{CmO}_{2}$, possibly $\mathrm{CmO}_{1} .83$, obtained on heating at $450^{\circ} \mathrm{C}$ in oxygen.

$a=5.435 \pm 0.001 \AA$ at room temperature

Supporting data on crystallography of $\mathrm{Cm}_{2} \mathrm{O}_{3}$.

n. Solubilities

Insoluble in water

o. Diffusion rates

Helium release from ${ }^{244} \mathrm{Cm}_{2} \mathrm{O}_{3}$ microspheres and pellets 42 has been correlated to obtain the "apparent diffusion coefficients" for microspheres in the range of 390 to $1200^{\circ} \mathrm{C}$ and for pellets in the range of 1100 to $1400^{\circ} \mathrm{C}$. 
o. Diffusion rates (continued)

Helium diffusion coefficient, $\mathrm{cm}^{2} / \mathrm{sec}$

Temperature,

Microspheres

$4.1 \times 10^{-10}$

$1.74 \times 10^{-9}$

$2.7 \times 10^{-9}$

$4.1 \times 10^{-9}$

$2.58 \times 10^{-9}$

$2.77 \times 10^{-9}$

$\mathrm{C}$

$3.45 \times 10^{-9}$

390

600

800

1000

1100

1200

1200

Cylindrical Pellets

$\begin{array}{ll}5 & \times 10^{-6} \\ 5.8 & \times 10^{-6} \\ 7 & \times 10^{-6} \\ 5 & \times 10^{-5}\end{array}$

1100

1200

1300

1400

7. Mechanical Properties
a. Hardness
b. Crush strength
$1900 \mathrm{~kg} / \mathrm{cm}^{2}$

$43\left(\mathrm{CeO}_{2}\right)$

8. Chemical Properties

a. Heat and free energy of formation, entropy

(1) Heat of formation

Phase

$-\triangle \mathrm{H}_{\mathrm{f}}^{\circ}\left(298^{\circ} \mathrm{K}\right), \mathrm{kcal} / \mathrm{mole}$

$$
\begin{aligned}
& \mathrm{CmO}_{1} .50 \\
& \mathrm{CmO}_{1} \cdot 71 \\
& \mathrm{CmO}_{1} .83 \\
& \mathrm{CmO}_{2} .00
\end{aligned}
$$
$215 \pm 7$
$218 \pm 10$ (est)
$225 \pm 10$ (est)
$236 \pm 8$ (est)

37

44

(2) Free energy of formation of $\mathrm{CmO}_{1} .50$

$\Delta G_{f}^{\circ}\left(298^{\circ} \mathrm{K}\right)=-205 \pm 7 \mathrm{kcal} / \mathrm{mole}(\mathrm{calc})$

32,37

(3) Entropy of $\mathrm{CmO}_{1} .50$

$\mathrm{S}_{298}^{\circ}=19.4 \mathrm{eu}$ 
b. Chemical reactions and reaction rates

(1) Oxidation of B-type $\mathrm{Cm}_{2} \mathrm{O}_{3}$ in oxygen ( $1 \mathrm{~atm}$ ) $16,30,31$, Heating

\begin{tabular}{|c|c|c|}
\hline $\begin{array}{l}\text { Heating } \\
\text { temp, }{ }^{\circ} \mathrm{C} \\
\end{array}$ & Time & Result \\
\hline 75 & $4 \mathrm{hr}$ & No oxidation \\
\hline 175 & $4 \mathrm{hr}$ & No oxidation \\
\hline 220 & $8 \mathrm{hr}$ & $80-90 \%$ oxidation to $\mathrm{CmO}_{2}$ \\
\hline 290 & $2 \mathrm{hr}$ & Complete oxidation to $\mathrm{CmO}_{2}$ \\
\hline 360 & $10 \mathrm{~min}$ & Oxidation to $40 \% \mathrm{Cm}_{7} \mathrm{O}_{12}-60 \% \mathrm{CmO}$ \\
\hline 360 & $30 \mathrm{~min}$ & Complete oxidation to $\mathrm{CmO}_{2}$ \\
\hline 450 & $15 \mathrm{~min}$ & Complete oxidation to $\mathrm{CmO}_{1.71}{ }^{a}$ \\
\hline 480 & $15 \mathrm{~min}$ & Complete oxidation to $\mathrm{CmO}_{1.71}$ \\
\hline 505 & $4 \mathrm{hr}$ & $70-80 \%$ oxidation to $\mathrm{CmO}_{1} .71$ \\
\hline 530 & $2 \mathrm{hr}$ & $<10 \%$ oxidation to $\mathrm{CmO}_{1.71}$ \\
\hline 570 & $2 \mathrm{hr}$ & No oxidation \\
\hline 750 & $4 \mathrm{hr}$ & No oxidation \\
\hline
\end{tabular}

aThe intermediate phase $\mathrm{CmO}_{1} .71$ is produced at somewhat lower temperatures $\left(450^{\circ} \mathrm{C}\right)$ by reoxidation of $\mathrm{Cm}_{2} \mathrm{O}_{3}$ rather than by thermal decomposition of $\mathrm{CmO}_{2}\left(470^{\circ} \mathrm{C}\right)$.

(2) Nitrogen - no reaction

(3) Water - possible hydration reaction

(4) Inorganic acids - soluble in acids

9. Biological Tolerances

Maximum permissible body burdens and maximum permissible concentrations of ${ }^{244} \mathrm{Cm}$ in air and in water are given under Section I.A.9.

10. Shielding Data

The dose rates are given under section I.A.10. 
1. Composition

a Radionuclidic abundance

See Section I.A.I.a.

b. Radiochemical purity

See Section I.A.I.b.

c. Chemical purity

See Section I.A.I.C.

2. Specific Power

a. $2.39 \mathrm{w} / \mathrm{g}$ of $100 \%$ pure $\mathrm{Cm}_{2} \mathrm{O}_{2} \mathrm{~S}\left(84.1 \%{ }^{244} \mathrm{Cm}\right.$ isotope) $4,5,6$ $2.32 \mathrm{w} / \mathrm{g}$ of $97 \%$ pure $\mathrm{Cm}_{2} \mathrm{O}_{2} \mathrm{~S}\left(81.6 \%{ }^{244} \mathrm{Cm}\right.$ isotope)

b. Specific power values are based on $81.3 \mathrm{Ci} / \mathrm{g}$ of ${ }^{244} \mathrm{Cm}$ and $34.95 \mathrm{w} / \mathrm{kCi}$ of ${ }^{244} \mathrm{Cm}$.

3. Radiation

The radiation is given under section I.A.3.

4. Critical Mass

See Section I.A.4.

5. Compatibility with Materials of Containment

6. Thermophysical Properties

a. Density

$9.95 \mathrm{~g} / \mathrm{cm}^{3}$

$46\left(\mathrm{Pu}_{2} \mathrm{O}_{2} \mathrm{~S}\right)$

b. Coefficient of thermal expansion

$29,30,31$

$0.60 \%$ over $25-680^{\circ} \mathrm{C}$

$\left(\mathrm{Cm}_{2} \mathrm{O}_{3}\right)$

$0.85 \%$ over $25-940^{\circ} \mathrm{C}$

$1.4 \%$ over $25-1300^{\circ} \mathrm{C}$

c. Specific heat and enthalpy

(1) Specific heat in cal $\mathrm{g}^{-1}{ }^{\circ} \mathrm{C}^{-1}$

$3.62 \times 10^{-2}+2.83 \times 10^{-5} \mathrm{~T}\left({ }^{\circ} \mathrm{K}\right)$

$33\left(\mathrm{Am}_{2} \mathrm{O}_{3}\right)$

(2) Enthalpy 
d. Temperatures of phase transformations

(1) Melting point

$$
2000^{\circ} \mathrm{C}
$$

$47\left(\mathrm{Ce}_{2} \mathrm{O}_{2} \mathrm{~S}\right)$

(2) Boiling point

$$
3130^{\circ} \mathrm{C}
$$

$33\left(\mathrm{Am}_{2} \mathrm{O}_{3}\right)$

e. Latent heats of phase transformations
$\triangle H$ fusion
$17 \mathrm{kcal} / \mathrm{mole}$

$\triangle H$ vaporization

$85 \mathrm{kcal} / \mathrm{mole}$

$33\left(\mathrm{Am}_{2} \mathrm{O}_{3}\right)$

$33\left(\mathrm{Am}_{2} \mathrm{O}_{3}\right)$

f. Vapor pressure

g. Thermal conductivity

Values for the thermal conductivity of curium oxysulfide have not been derived but probably are in the same order of magnitude as the values for $\mathrm{Cm}_{2} \mathrm{O}_{3}$ which are given in section I.B.6.g.

h. Thermal diffusivity

Values for the thermal diffusivity of curium oxysulfide have not been derived but probably are in the same order of magnitude as the values for $\mathrm{Cm}_{2} \mathrm{O}_{3}$ which are given in section I.B.6.h.

i. Viscosity

j. Surface tension

k. Total hemispherical emittance

1. Spectral emissivity

$$
0.20 \text { to } 0.57
$$

The emissivity value depends on the roughness of the material surface, radiation effects, and the presence of impurities.

m. Crystallography

Hexagonal
$\mathrm{a}=4.008 \AA$
$\mathrm{c}=6.769 \AA$

The cell constants should be slightly smaller for $\mathrm{Cm}_{2} \mathrm{O}_{2} \mathrm{~S}$ due to the actinide contraction.

n. Solubilities

(1) Soluble in strong acids $\left(\mathrm{Ce}_{2} \mathrm{O}_{2} \mathrm{~S}\right)$

(2) Insoluble in acetic acid $\left(\mathrm{Ce}_{2} \mathrm{O}_{2} \mathrm{~S}\right)$ 
o. Diffusion rates

7. Mechanical Properties
a. Hardness
b. Crush strength

8. Chemical Properties

a. Heat and free energy of formation, entropy

(1) Heat of formation $\Delta \mathrm{H}_{\mathrm{f}}^{\circ}=-430 \mathrm{kcal} / \mathrm{mole}$ (approximated by $\mathrm{Ce}_{2} \mathrm{O}_{2} \mathrm{~S}$ ) $\quad 47$

(2) Free energy of formation $\Delta \mathrm{F}_{f}^{\circ}=-414 \mathrm{kcal} / \mathrm{mole}$ (calculated by $\left.\Delta F_{f}^{\circ}=\Delta H_{f}^{\circ}-T \Delta S_{f}^{\circ}\right)$

(3) Entropy $\mathrm{S}_{298}=34.3 \mathrm{eu}$ (calculated by Latimer's method) 49

b. Chemical reactions and reaction rates 46

(1) Air at room temperature - slow

(2) Air at elevated temperature - fast

(3) Water at room temperature - no reaction

(4) Inorganic acids at room temperature - reacts

9. Biological Tolerances

Maximum permissible body burdens and maximum permissible concentrations of ${ }^{244} \mathrm{Cm}$ in air and in water are given in the ${ }^{244} \mathrm{Cm}$ Metal Source Form, Section I.A.9.

10. Shielding Data

The radiation dose rates are given under the ${ }^{244} \mathrm{Cm}$ Metal Source Form, Section I.A.10. 
D. CURIUM FLUORIDE $\left(\mathrm{CmF}_{3}\right)$

\section{Composition}
a. Radionuclidic abundance
See Section I.A.I.a.
b. Radiochemical purity
See Section I.A.I.b.
c. Chemical purity
See Section I.A.I.C.

2. Specific Power
$\begin{array}{ll}\text { a. } & 2.19 \mathrm{w} / \mathrm{g} \text { of } 100 \% \text { pure } \mathrm{CmF}_{3}\left(77.1 \%{ }^{244} \mathrm{Cm} \text { isotope }\right) \\ & 2.12 \mathrm{w} / \mathrm{g} \text { of } 97 \% \text { pure } \mathrm{CmF}_{3}\left(74.8 \%{ }^{244} \mathrm{Cm} \text { isotope) }\right.\end{array}$
$4,5,6$
b. Specific power values are based on $81.3 \mathrm{Ci} / \mathrm{g}$ of ${ }^{244} \mathrm{Cm}(100 \%)$ and $34.95 \mathrm{w} / \mathrm{kCi}$ of ${ }^{244} \mathrm{Cm}$.

3. Radiation

The radiation is given under section I.A.3.

4. Critical Mass

See Section I.A.4.

5. Compatibility with Materials of Containment

6. Thermophysical Properties

a. Density

$$
9.80 \mathrm{~g} / \mathrm{cm}^{3}
$$

b. Coefficient of thermal expansion

$a=19.74 \times 10^{-6}+2.62 \times 10^{-8} t+0.15 \times 10^{-10} t^{2}$

$51\left(\mathrm{BaF}_{2}\right)$

( $t$ is in ${ }^{\circ} \mathrm{C}$ with a temperature range of $26-296^{\circ} \mathrm{C}$ )

c. Specific heat and enthalpy

(1) Specific heat in cal $\mathrm{g}^{-1}{ }^{\circ} \mathrm{C}^{-1}$

$$
7.21 \times 10^{-2}+2.06 \times 10^{-5} \mathrm{~T}\left({ }^{\circ} \mathrm{K}\right)
$$

(2) Enthalpy in cal

$$
\begin{aligned}
& \mathrm{H}_{\mathrm{f}}-\mathrm{H}_{298}=21 \mathrm{~T}+3.5 \times 10^{-3} \mathrm{~T}^{2} \\
& \text { (estimated from other actinide data) }
\end{aligned}
$$


d. Temperatures of phase transformations

(I) Melting point $1406^{\circ} \mathrm{C}$

(2) Boiling point $2330^{\circ} \mathrm{C}$

This value is the average of the boiling points of $\mathrm{LaF}_{3}, \mathrm{CeF}_{3}$, and $\mathrm{PrF}_{3}$.

e. Latent heats of phase transformations

$\Delta \mathrm{H}$ fusion $\quad 9 \mathrm{kcal} / \mathrm{mole}$

$\Delta \mathrm{H}$ vaporization $62 \mathrm{kcal} / \mathrm{mole}$

f. Vapor pressure

Vapor pressure, torr

$$
5.07 \times 10^{-7}
$$

$7.18 \times 10^{-6}$

$1.486 \times 10^{-4}$

$1.725 \times 10^{-3}$

$5.820 \times 10^{-3}$
Temperature, ${ }^{\circ} \mathrm{C}$

853

943

1033

1141

1196

Vapor pressures are for $\mathrm{AmF}_{3}$.

g. Thermal conductivity

Thermal conductivity, cal $\mathrm{cm}^{-1} \mathrm{sec}^{-1}{ }^{\circ} \mathrm{C}^{-1}$ 0.0296 0.0251
$33\left(\mathrm{CeF}_{3}\right)$

$33\left(\mathrm{CeF}_{3}\right)$

53

h. Thermal diffusivity

Thermal diffusivity, $\mathrm{cm}^{2} / \mathrm{sec}$ Temperature,

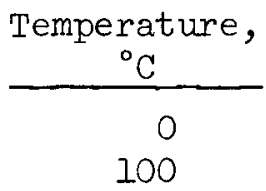

100

$$
\begin{array}{r}
0.0399 \\
0.0321
\end{array}
$$

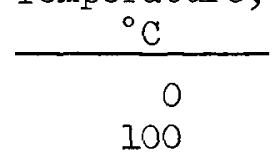

Calculated by dividing the product of the specific heat and the room temperature density into the thermal conductivity.

i. Viscosity

j. Surface tension

k. Total hemispherical emittance

A value of 0.9 can be assumed.

1. Spectral emissivity 
m. Crystallography

Hexagonal, LaF 3 -type, space group $\mathrm{P}_{3} / \mathrm{mmc}$

n. Solubilities

o. Diffusion rates

7. Mechanical Properties

a. Hardness

b. Crush strength

8. Chemical Properties

a. Heat and free energy of formation, entropy

(I) Heat of formation

$\Delta \mathrm{H}_{\mathrm{f}}^{\circ}=-357 \mathrm{kcal} / \mathrm{mole}$

(estimated from other actinide data)

(2) Free energy of formation

$\Delta F_{f}^{\circ}=-339 \mathrm{kcal} / \mathrm{mole}$

(3) Entropy

$\mathrm{S}_{298}^{\circ}=29 \mathrm{eu}$ (estimated from other actinide data)

b. Chemical reactions and reaction rates

(1) Air at room temperature - no reaction

(2) Air at elevated temperature - forms oxyfluoride

(3) Nitrogen - no reaction

(4) Water - insoluble

(5) Inorganic acids - insoluble in weak inorganic acid

9. Biological Tolerances

Maximum permissible body burdens and maximum permissible concentrations of ${ }^{244} \mathrm{Cm}$ in air and in water are given under section I.A.9.

10. Shielding Data

The dose rates are given under section I.A.IO. 
II. CURIUM-242

A. CURIUM-242 OXIDE CERMET

Half-life: 163 d

$1,5,7,9$

1. Composition

a. Radionuclidic abundance

The composition of the product will depend on the irradiation history of the ${ }^{24 I} \mathrm{Am}$ target as well as the cooling time after removal from the pile. The product is expected to be at least $40 \%{ }^{242} \mathrm{Cm}$. If it is not this high, an Am-Cm separation is used to lower the americium content of the product.

The analysis for a typical batch of ${ }^{24 l} \mathrm{Am}$ with a total integrated neutron dose of $1.3 \times 10^{21}$ and with a 90-day cooling and processing period (with all the plutonium removed) is as follows:

\begin{tabular}{lr} 
Isotope & $\%$ Abundan \\
\hline $24 I \mathrm{Am}$ & 47.5 \\
$242 \mathrm{Am}$ & 1.6 \\
$243 \mathrm{Am}$ & 7.7 \\
$242 \mathrm{Cm}$ & 41.9 \\
$243 \mathrm{Cm}$ & 0.5 \\
$244 \mathrm{Cm}$ & 0.8
\end{tabular}

The decay of ${ }^{242} \mathrm{Cm}$ to ${ }^{238} \mathrm{Pu}$ is illustrated in the following table. A $10-\mathrm{g}$ product with $40 \%{ }^{242} \mathrm{~cm}$ and $60 \%$ other actinides is assumed. The decay is shown for 163 days.

$\begin{array}{ccc}\text { Time, days } & \frac{242 \mathrm{Cm}, \mathrm{g}}{2} & \frac{238 \mathrm{Pu}, \mathrm{g}}{2} \\ 16 & 3.00 & 0 \\ 32 & 3.73 & 0.27 \\ 65 & 3.48 & 0.52 \\ 81.5 & 3.03 & 0.97 \\ 98 & 2.83 & 1.17 \\ 163 & 2.46 & 1.54\end{array}$

The oxide mixture will be $\mathrm{AmO}_{2}$ and $\mathrm{Cm}_{2} \mathrm{O}_{3}$. This will be suspended in a neutral matrix material to give the prescribed power density:

30 vol \% oxide mixture 70 vol \% matrix material 
b. Radiochemical purity

The only important heat contributor to the ${ }^{242} \mathrm{Cm}$ source material is $242 \mathrm{Cm}$. The following table shows the contribution of each isotope to $10 \mathrm{~g}$ of the oxide mixture.

Heat Contribution of Each Isotope of the ${ }^{242} \mathrm{Cm}$ Product

\begin{tabular}{llccccc}
\hline \multirow{2}{*}{ Nuclide } & Half- & Specific & \% of & \multicolumn{2}{c}{ Heat contribution } \\
\cline { 6 - 7 } & life & activity, w/g & nuclide & watts & $\%$ \\
\hline${ }^{241} \mathrm{Am}$ & $458 \mathrm{y}$ & 0.106 & 47.5 & 0.50 & 0.1 \\
${ }^{242} \mathrm{Am}$ & $152 \mathrm{y}$ & 0.034 & 1.6 & 0.05 & 0.01 \\
${ }^{243} \mathrm{Am}$ & $7650 \mathrm{y}$ & 0.006 & 7.7 & 0.005 & 0.001 \\
${ }^{242} \mathrm{Cm}$ & $163 \mathrm{~d}$ & 120.0 & 41.9 & 502.8 & 99.8 \\
$243 \mathrm{Cm}$ & $32 \mathrm{y}$ & 1.44 & 0.5 & 0.07 & 0.015 \\
${ }^{244} \mathrm{Cm}$ & $18.1 \mathrm{y}$ & 2.78 & 0.8 & 0.22 & 0.05 \\
$238 \mathrm{Pu}$ & $89 \mathrm{y}$ & 0.55 & & & \\
\hline
\end{tabular}

The ${ }^{242} \mathrm{Cm}$ product has contained up to $30 \mathrm{Ci}$ of ${ }^{144} \mathrm{Ce}$ per $8.33 \mathrm{~g}$ of ${ }^{242} \mathrm{Cm}$. Trace amounts of ${ }^{103^{\mathrm{Ru}}-{ }^{106} \mathrm{Ru} \text { and }}$ $95 \mathrm{Zr}-{ }^{95} \mathrm{Nb}$ have been found in the feed but do not contribute materially to the power or radiation of the source.

The above contaminations can be reduced to much lower levels by additional processing.

\section{Specific Power}

a. $42.8 \mathrm{w} / \mathrm{g}$ of $\mathrm{AmO}_{2}-\mathrm{Cm}_{2} \mathrm{O}_{3}\left(35.7 \%{ }^{242} \mathrm{Cm}\right.$ metal $)$

It is assumed that there are $3320 \mathrm{Ci} / \mathrm{g}$ of ${ }^{242} \mathrm{Cm}$ and $36.1 \mathrm{w} / \mathrm{kCi}$ of $242 \mathrm{Cm}$.

b. $\quad{ }_{242} 186 \mathrm{Ci}$ of ${ }^{242} \mathrm{Cm}$ per gram of $\mathrm{AmO}_{2}-\mathrm{Cm}_{2} \mathrm{O}_{3}(35.7 \%$

3. Radiation

a. Alpha particles

\begin{tabular}{|c|c|c|c|c|c|}
\hline Nuclide & $\begin{array}{l}\operatorname{Max} E, \\
\text { Mev }\end{array}$ & $\begin{array}{c}\text { Av E, } \\
\text { Mev }\end{array}$ & $\begin{array}{c}\text { Abundance, } \\
\%\end{array}$ & $\mathrm{w} / \mathrm{kCi}$ & $\begin{array}{l}\text { Particles } \\
\mathrm{w}^{-1} \mathrm{sec}^{-1}\end{array}$ \\
\hline \multirow[t]{2}{*}{${ }^{242} \mathrm{Cm}$} & 6.11 & 6.11 & $73 \cdot 7$ & \multirow{2}{*}{36.10} & $0.755 \times 10^{12}$ \\
\hline & 6.066 & 6.066 & 26.3 & & $0.270 \times 10^{12}$ \\
\hline
\end{tabular}


a. Alpha particles (continued)

The amount of helium produced by alpha decay of ${ }^{242} \mathrm{Cm}$ as a function of time is given in the following table.

\begin{tabular}{ccc}
\hline \multirow{2}{*}{$\begin{array}{c}\text { Volume of helium, } \\
\mathrm{cm}^{3} \text { of } \mathrm{He} \text { per g of }{ }^{242} \mathrm{Cm}\end{array}$} & \multicolumn{2}{c}{ Time } \\
\cline { 3 - 3 } 11.9 & 32.6 & 0.2 \\
22.4 & 65.2 & 0.4 \\
31.5 & 97.8 & 0.6 \\
39.4 & 130.4 & 0.8 \\
46.3 & 163 & 1.0 \\
59.8 & 244 & 1.5 \\
69.4 & 326 & 2.0 \\
80.9 & 489 & 3.0 \\
86.7 & 652 & 4.0 \\
89.6 & 815 & 5.0 \\
92.4 & 1630 & 10.0 \\
\hline$a_{\text {Standard conditions. }}$ & & \\
\hline
\end{tabular}

b. Beta particles

None

c. Gamma

In addition to the gammas from the alpha decay, there 7 are the prompt and fission-product gammas from the spontaneous fission of ${ }^{242} \mathrm{Cm}\left(\mathrm{T}_{1} / 2=7.2 \times 10^{6} \mathrm{y}\right)$. The gamma-emission rates are given in the following table.

\begin{tabular}{|c|c|}
\hline $\begin{array}{l}\text { Gamma-emission rate, } \\
\text { photons } \sec ^{-1} g^{-1}\end{array}$ & $\begin{array}{c}\text { Photon energy, } \\
\text { Mev }\end{array}$ \\
\hline
\end{tabular}

Curium-242 Gammas

$\begin{array}{ll}0.27 \times 10^{14} & 0.044 \\ 1.42 \times 10^{10} & 0.10 \\ 2.83 \times 10^{9} & 0.158\end{array}$

Prompt Gammas

$2.44 \times 10^{7}$

$6.09 \times 10^{6}$

1.0

$6.45 \times 10^{6}$

1.5

$1.15 \times 10^{6}$

2.3

$1.52 \times 10^{6}$

3.0

5.0 


\begin{tabular}{c}
$\begin{array}{c}\text { Gamma-emission rate, } \\
\text { photons } \sec ^{-1} \mathrm{~g}^{-1}\end{array}$ \\
\hline
\end{tabular}

Fission-Product Gammas

\begin{tabular}{cl}
$2.16 \times 10^{7}$ & 0.63 \\
$7.99 \times 10^{6}$ & 1.1 \\
$9.36 \times 10^{6}$ & 1.55 \\
$1.80 \times 10^{6}$ & 2.38 \\
$2.66 \times 10^{6}$ & 2.75 \\
\hline$a_{120-w}$ source.
\end{tabular}

d. Bremsstrahlung

None

e. Neutrons

$2.30 \times 10^{7}$ neutrons $\mathrm{sec}^{-1} \mathrm{~g}^{-1}$ of ${ }^{242} \mathrm{Cm}$ from spontaneous fission ( $120-\mathrm{w}$ source)

$2.0 \times 10^{7}$ neutrons $\mathrm{sec}^{-1} \mathrm{~g}^{-1}$ of ${ }^{242} \mathrm{Cm}$ from $(\alpha, \mathrm{n})$ reaction of oxygen in $\mathrm{Cm}_{2} \mathrm{O}_{3}$ ( $1.20-\mathrm{w}$ source)

The energy distribution of spontaneous fission neutrons 4 from ${ }^{242} \mathrm{Cm}$ is given in the following table.

Spontaneous Fission Neutrons from Curium-242

\begin{tabular}{ll}
$\begin{array}{c}\text { Energy, } \\
\text { Mev }\end{array}$ & \multicolumn{2}{c}{$\begin{array}{c}\text { Abundance, } \\
\text { neutrons } \\
\mathrm{sec}^{-1} \mathrm{~g}^{-1} \text { of }{ }^{242} \mathrm{Cm}\end{array}$} \\
\hline $0.3-0.4$ & $7.7 \times 10^{5}$ \\
$0.4-0.6$ & $1.6 \times 10^{6}$ \\
$0.6-0.8$ & $1.6 \times 10^{6}$ \\
$0.8-1.0$ & $1.4 \times 10^{6}$ \\
$1.0-1.2$ & $1.4 \times 10^{6}$ \\
$1.2-1.4$ & $1.4 \times 10^{6}$ \\
$1.4-1.6$ & $1.2 \times 10^{6}$ \\
$1.6-1.8$ & $1.1 \times 10^{6}$ \\
$1.8-2.0$ & $1.0 \times 10^{6}$ \\
$2.0-2.2$ & $9.1 \times 10^{5}$ \\
$2.2-2.4$ & $8.4 \times 10^{5}$ \\
$2.4-2.6$ & $8.0 \times 10^{5}$ \\
$2.6-2.8$ & $6.5 \times 10^{5}$ \\
$2.8-3.0$ & $5.5 \times 10^{5}$ \\
$3.0-3.2$ & $5.0 \times 10^{5}$ \\
$3.2-3.4$ & $5.0 \times 10^{5}$ \\
$3.4-3.6$ & $4.7 \times 10^{5}$ \\
$3.6-3.8$ & $3.7 \times 10^{5}$ \\
$3.8-4.0$ & $4.1 \times 10^{5}$
\end{tabular}


Spontaneous Fission Neutrons (continued)

\begin{tabular}{cc}
$\begin{array}{c}\text { Energy, } \\
\text { Mev }\end{array}$ & \multicolumn{2}{c}{$\begin{array}{c}\text { Abundance, } \\
\text { neutrons } \mathrm{sec}^{-1} \mathrm{~g}^{-1} \text { of } 242 \mathrm{Cm}\end{array}$} \\
\hline $4.0-4.4$ & $5.2 \times 10^{5}$ \\
$4.4-4.8$ & $4.4 \times 10^{5}$ \\
$4.8-5.2$ & $3.2 \times 10^{5}$ \\
$5.2-5.6$ & $2.5 \times 10^{5}$ \\
$5.6-6.0$ & $1.9 \times 10^{5}$ \\
$6.0-6.4$ & $1.5 \times 10^{5}$ \\
$6.4-6.8$ & $1.1 \times 10^{5}$ \\
$6.8-7.2$ & $7.5 \times 10^{4}$ \\
$7.2-7.6$ & $5.6 \times 10^{4}$ \\
$7.6-8.0$ & $4.7 \times 10^{4}$ \\
$8.0-8.8$ & $5.0 \times 10^{4}$ \\
$8.8-9.6$ & $1.5 \times 10^{4}$ \\
$9.6-10.4$ & $1.6 \times 10^{4}$ \\
$10.4-11.2$ & $1.0 \times 10^{4}$ \\
$11.2-12.8$ & $7.1 \times 10^{3}$ \\
\hline
\end{tabular}

a $120-w$ source.

The energy distribution of neutrons occurring as a result of a collision of fast alpha particles from ${ }^{242} \mathrm{Cm}$ decay with oxygen atoms in $\mathrm{Cm}_{2} \mathrm{O}_{3}$ is given in the following table.

Neutrons from $(\alpha, n)$ Reactions with Oxygen

\begin{tabular}{ll}
\hline $\begin{array}{c}\text { Energy, } \\
\text { Mev }\end{array}$ & $\begin{array}{c}\text { Abundance, } \\
\mathrm{sec}^{-1} \mathrm{~g}^{-1} \text { of } 242 \mathrm{Cm}\end{array}$ \\
\hline 0.2 & $5.0 \times 10^{3}$ \\
0.4 & $1.0 \times 10^{4}$ \\
0.6 & $2.0 \times 10^{4}$ \\
0.8 & $2.5 \times 10^{4}$ \\
1.0 & $7.6 \times 10^{4}$ \\
1.2 & $1.5 \times 10^{5}$ \\
1.4 & $2.8 \times 10^{5}$ \\
1.6 & $4.5 \times 10^{5}$ \\
1.8 & $7.6 \times 10^{5}$ \\
2.0 & $1.0 \times 10^{6}$ \\
2.2 & $1.3 \times 10^{6}$ \\
2.4 & $1.7 \times 10^{6}$ \\
2.6 & $2.0 \times 10^{6}$ \\
2.8 & $2.1 \times 10^{6}$ \\
3.0 & $2.1 \times 10^{6}$ \\
3.2 & $2.1 \times 10^{6}$ \\
3.4 & $1.8 \times 10^{6}$
\end{tabular}




\begin{tabular}{|c|c|}
\hline $\begin{array}{c}\text { Energy, } \\
\text { Mev }\end{array}$ & $\begin{array}{c}\text { Abundance, } \\
\text { neutrons } \mathrm{sec}^{-1} \mathrm{~g}^{-1} \text { of } 242 \mathrm{~cm}\end{array}$ \\
\hline $\begin{array}{l}3.6 \\
3.8\end{array}$ & $\begin{array}{l}1.5 \times 10^{6} \\
1.0 \times 10^{6}\end{array}$ \\
\hline $\begin{array}{l}4.0 \\
4.2 \\
4.4 \\
4.6 \\
4.8\end{array}$ & $\begin{array}{l}6.5 \times 10^{5} \\
4.0 \times 10^{5} \\
2.8 \times 10^{5} \\
1.8 \times 10^{5} \\
5.0 \times 10^{4}\end{array}$ \\
\hline
\end{tabular}

$a_{120-w}$ source.

4. Critical Mass

5. Compatibility with Materials of Containment

See ORNL-4359, Compatibility Data Sheets for Cerium-144, Cesium-137, Curium, and Strontium-90 (classified).

6. Thermophysical Properties

The thermophysical properties of a ${ }^{242} \mathrm{Cm}$ oxide cermet will depend on the individual properties of the oxide and matrix material. With the selection of the proper refractory metal as the matrix material, it should be possible to reach a

$0.06 \mathrm{cal} \mathrm{cm}^{-1} \mathrm{sec}^{-1}{ }^{\circ} \mathrm{C}^{-1}$ thermal conductivity for the cermet.

7. Mechanical Properties

The mechanical properties of the metal-oxide mixture will depend strongly on the properties of the matrix material.

8. Chemical Properties

The chemical properties will depend on the individual

properties of the oxide and matrix material.

9. Biological Tolerances

The ${ }^{242} \mathrm{Cm}$ tolerances taken from reference 26 are given in the table on the following page. 
Maximum Permissible Body Burdens and Maximum Permissible Concentrations for Radionuclides in Air and in Water for Occupational Exposure ${ }^{26}$

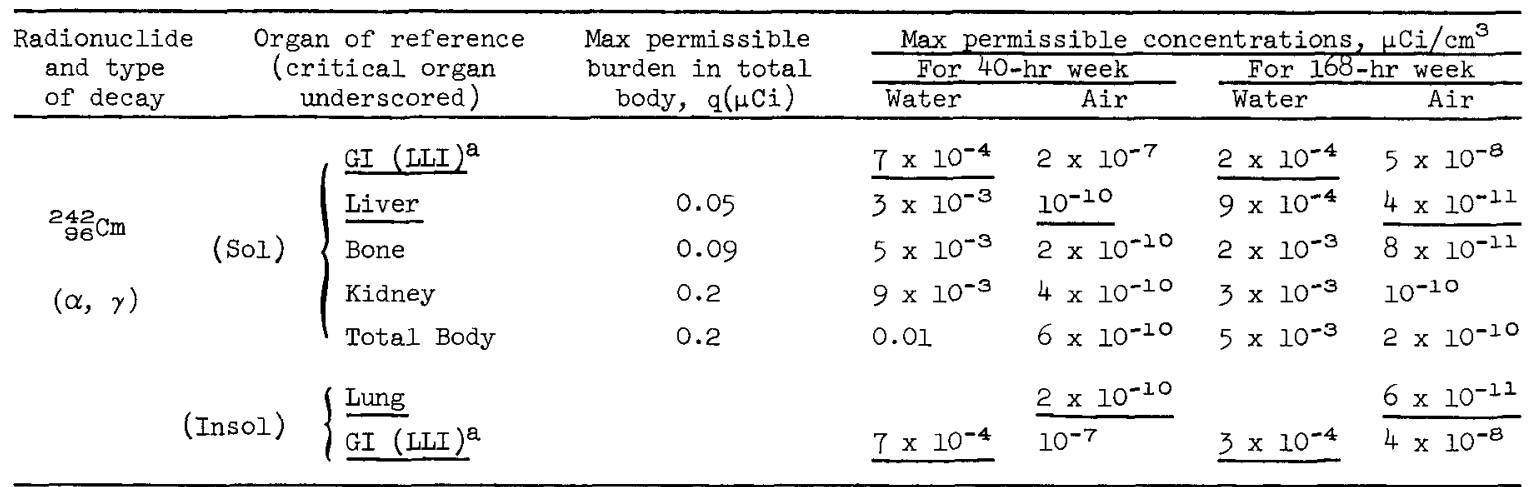

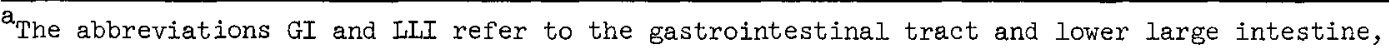
respectively.

\section{Shielding Data}

Gamma dose rates with water, iron, lead, and uranium shielding are given in Figs. 8-12 for ${ }^{242} \mathrm{Cm}$ power sources of 100, 200, 500, 1000, 2000, 5000, 10,000, and 20,000 w. Neutron dose rates with water shielding are given in Fig. 13. Neutron dose rates on shielding with $\mathrm{Be}, \mathrm{Ch}, \mathrm{CH}_{2}$, or LiH can be estimated by using Fig. 13 in conjunction with Fig. 7 .

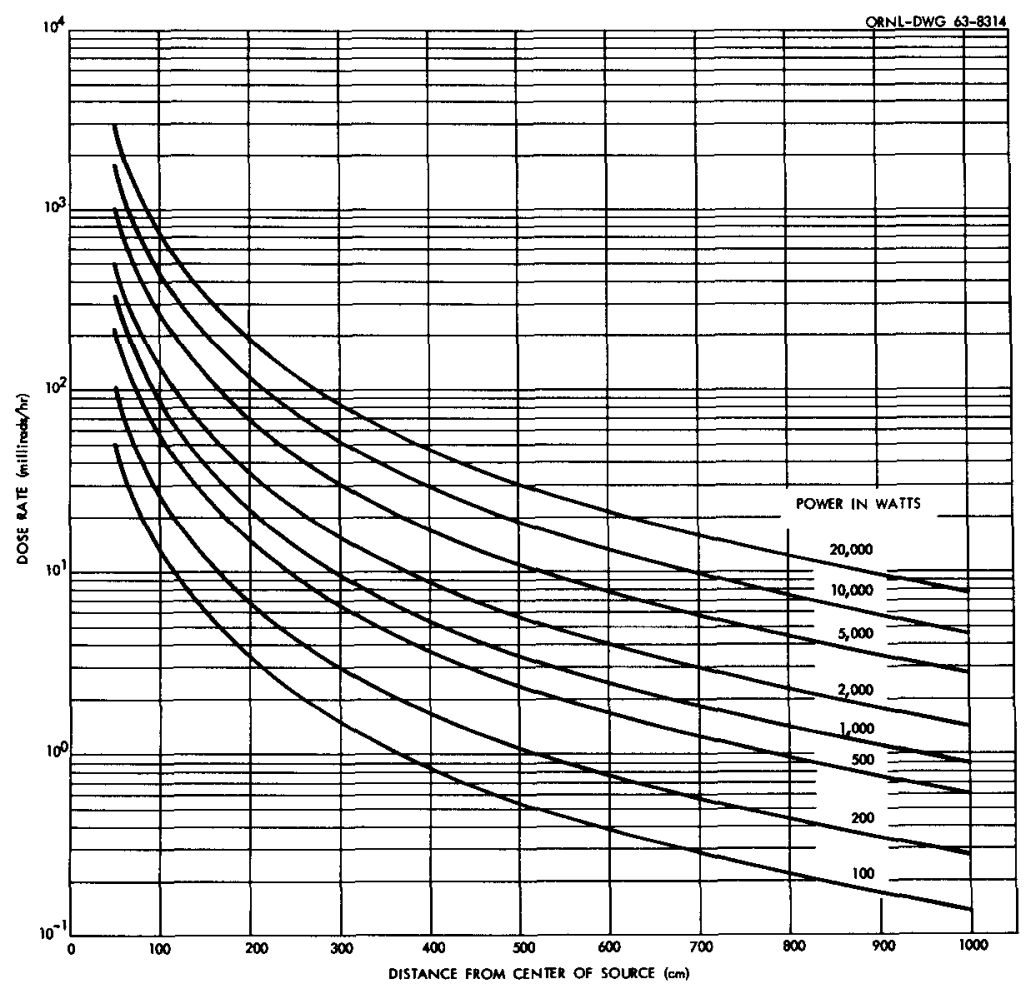

Fig. 8. Gamma Dose Rates from Unshielded Isotopic Power Sources of Curium-242 as a Function of Distance from Center of Source. 


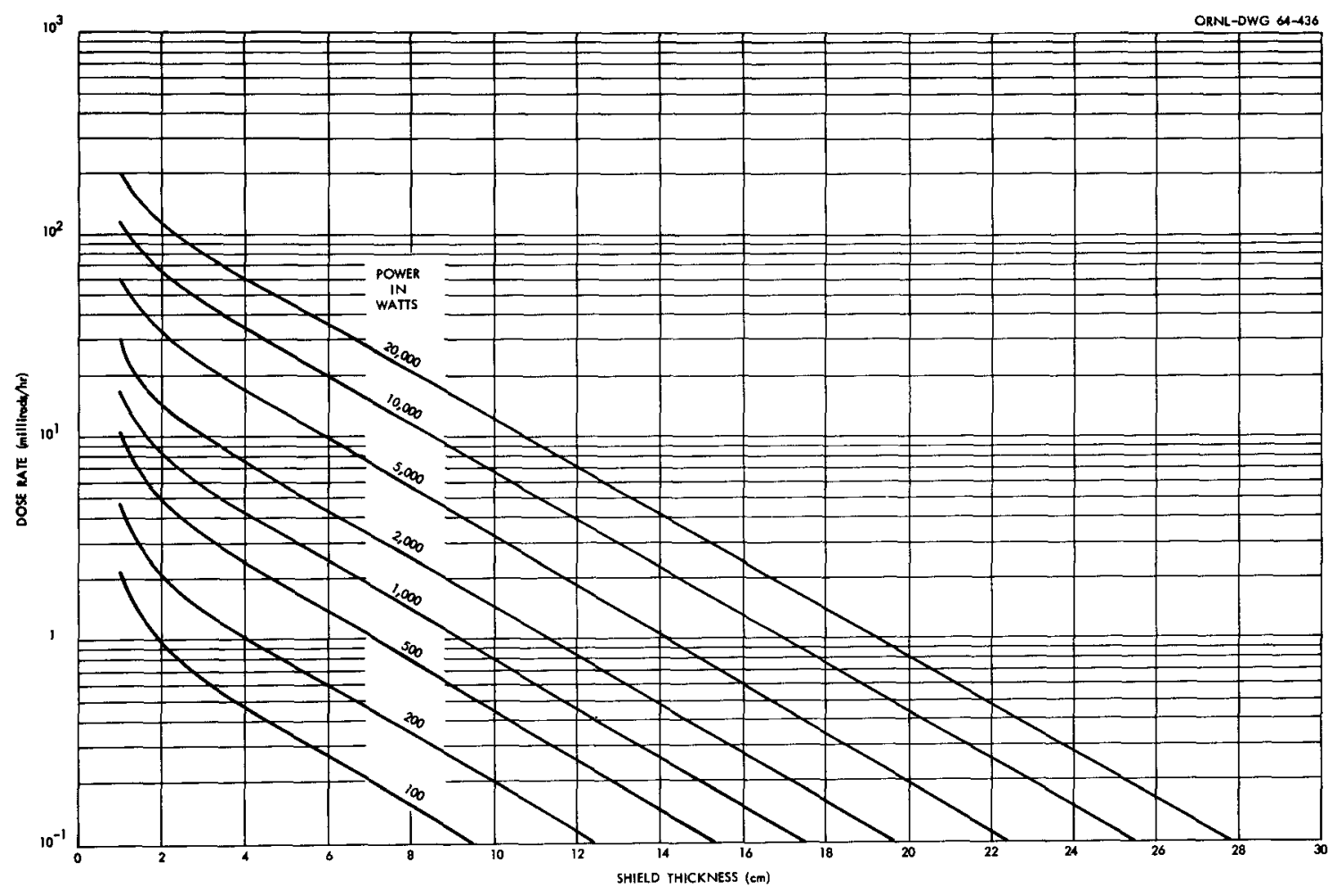

Fig. 9. Gamma Dose Rates from Iron-Shielded Isotopic Power Sources of Curium-242. Center of source to dose point separation distance is $100 \mathrm{~cm}$.

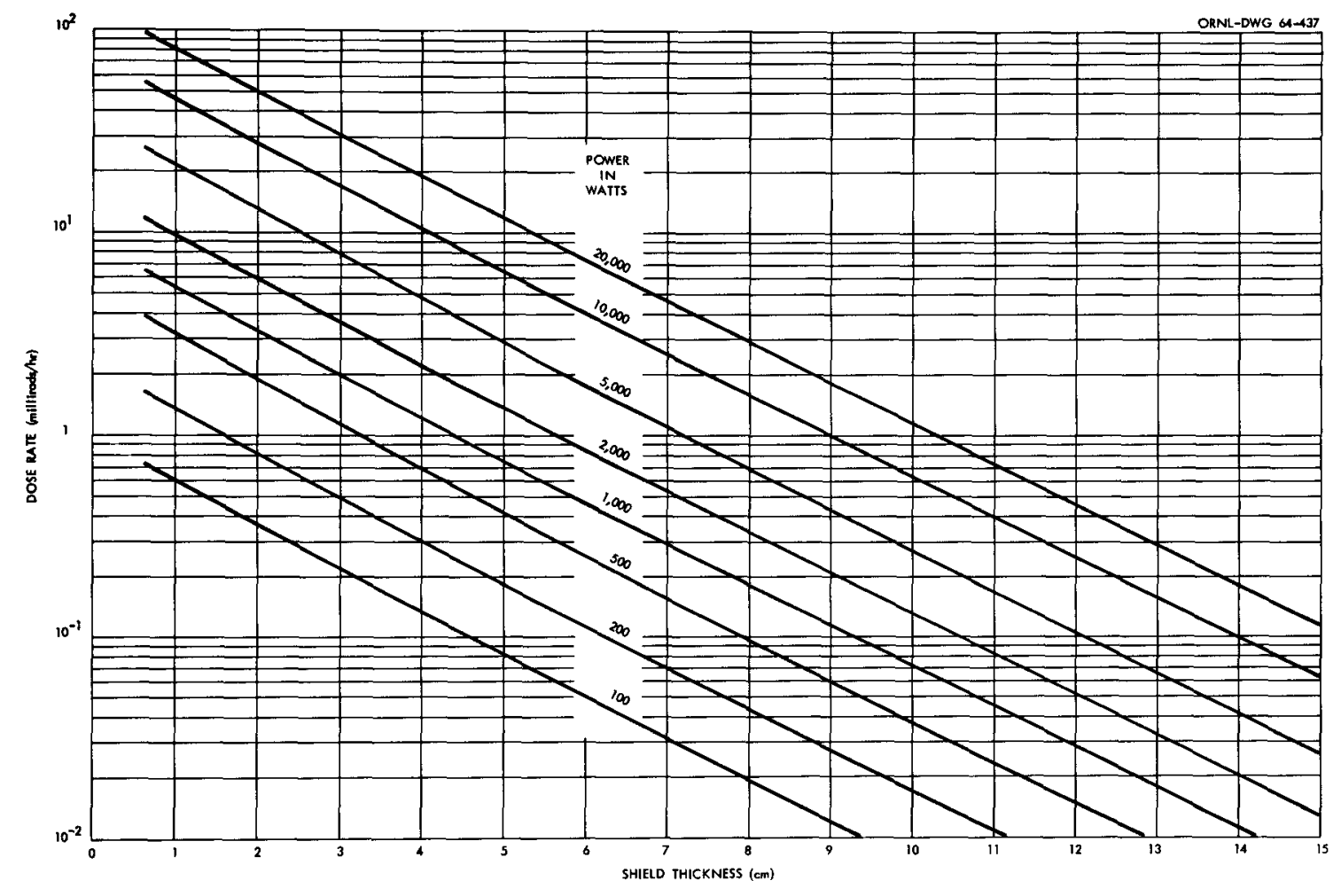

Fig. 10. Gamma Dose Rate from Lead-Shielded Isotopic Power Sources of Curium-242. Center of source to dose point separation distance is $100 \mathrm{~cm}$. 


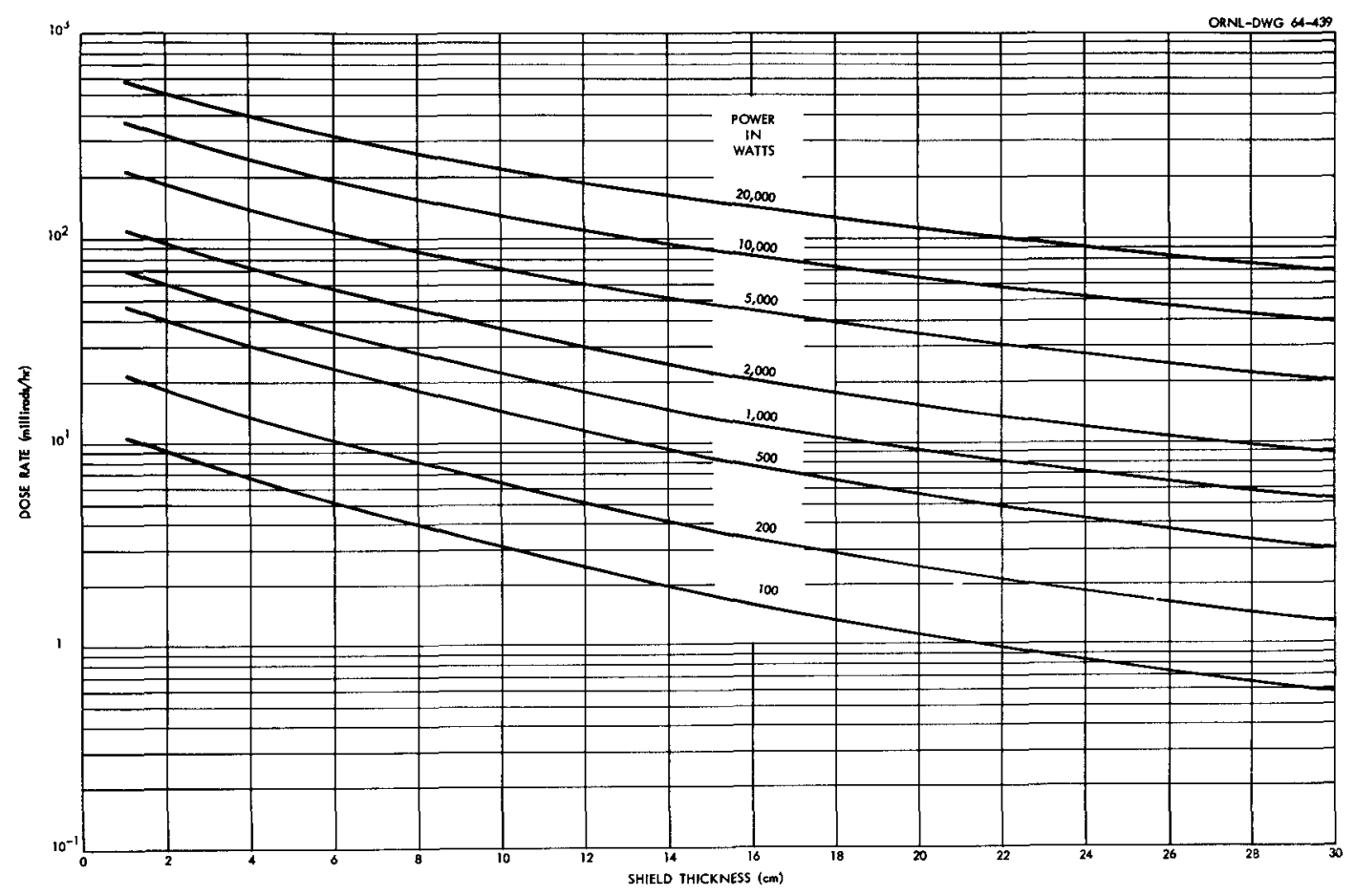

Fig. 11. Gamma Dose Rates from Water-Shielded Isotopic Power Sources of Curium-242. Center of source to dose point separation distance is $100 \mathrm{~cm}$.

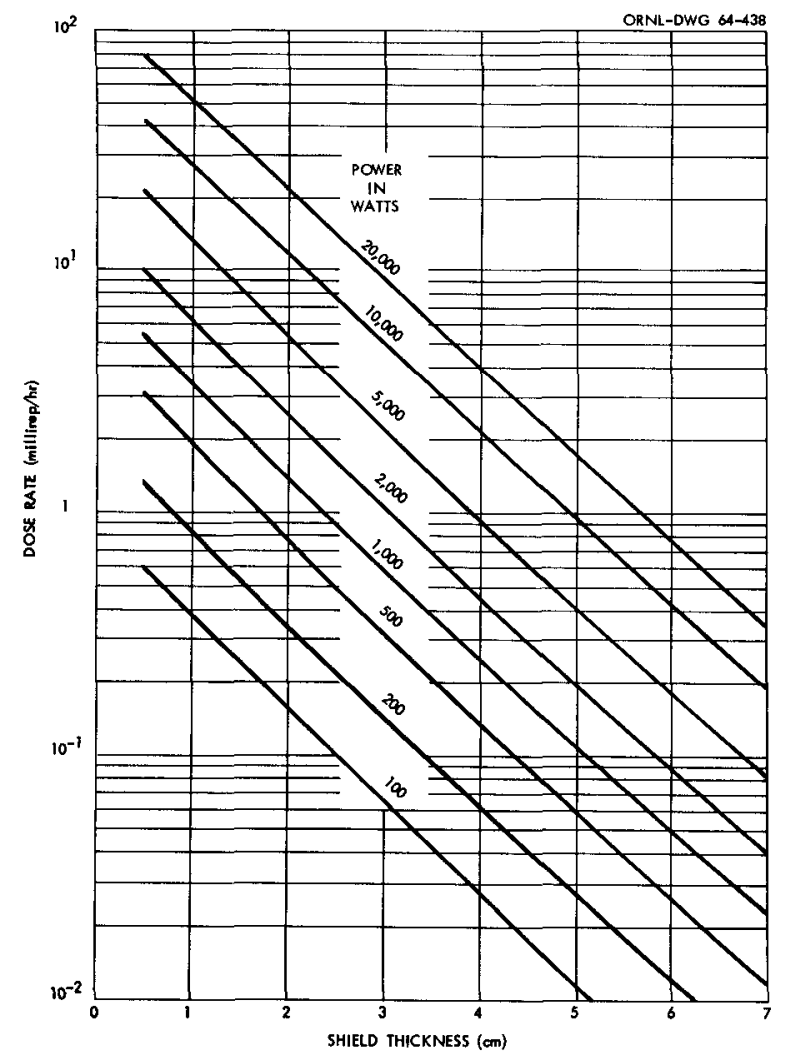

Fig. 12. Gamma Dose Rates from Uranium-Shielded Isotopic Power Sources of Curium-242. Center of source to dose point separation distance is $100 \mathrm{~cm}$.

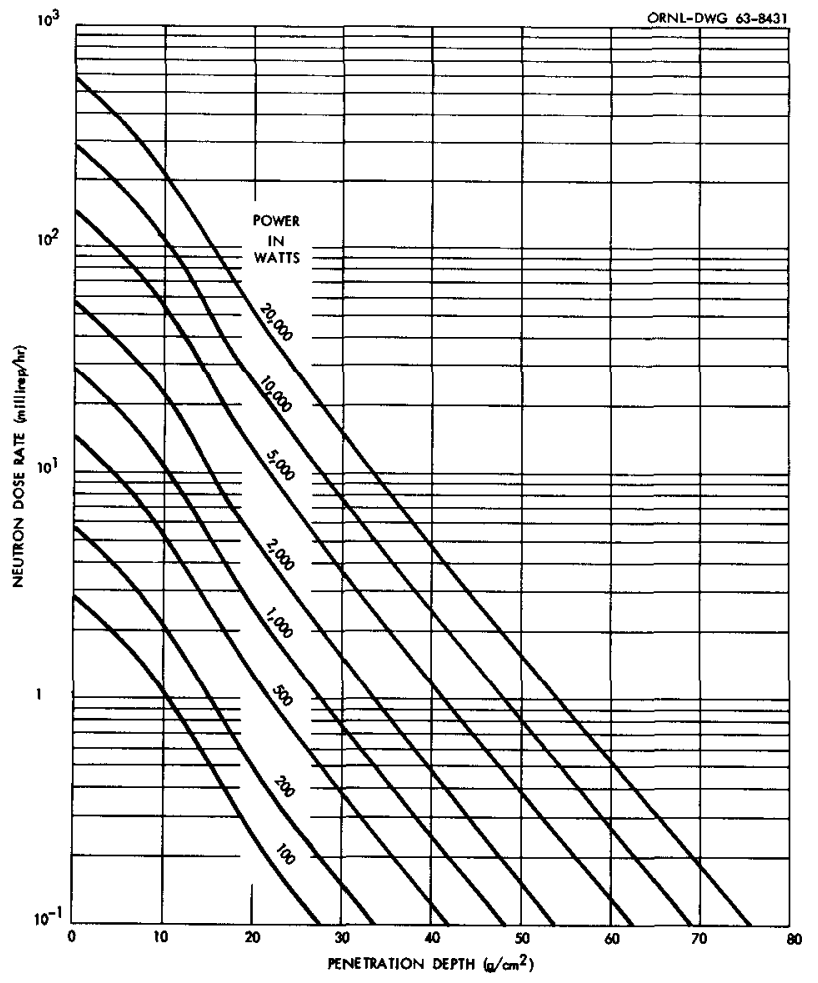

Fig. 13. Neutron Dose Rates from Water-Shielded Isotopic Power Sources of Curium-242 as a Function of Penetration Depth of Shielding Material. Center of source to dose point separation distance is $100 \mathrm{~cm}$. Refer to Fig. 7 for dose rates through other materials 


\section{REFERENCES FOR CURIUM}

1. Knolls Atomic Power Laboratory, General Electric Company, Chart of the Nuclides, 7th ed., revised to June 1964.

2. W. C. Bentley, Alpha Half-life of ${ }^{244} \mathrm{Cm}$, J. Inorg. Nucl. Chem. 30: 2007-9 (1968).

3. D. G. Ebenhack, Savannah River Laboratory, private communication, November 1968.

4. D. H. Stoddard, Radiation Properties of ${ }^{244} \mathrm{Cm}$ Produced for Isotopic Power Generators, USAEC Rpt. DP-939, Savannah River Laboratory (November 1964).

5. B. S. Dzhelepov and L. K. Peker, Decay Schemes of Radioactive Nuclei, Pergamon Press, London and New York, 1961.

6. D. Metta et al., Nuclear Constants of Nine Transplutonium Nuclides, Abstracts of Papers, 148th Am. Chem. Soc. Meeting, Chicago, 1964, p. 8R.

7. E. D. Arnold, Handbook of Shielding Requirements and Radiation Characteristics of Isotopic Power Sources for Terrestrial, Marine, and Space Applications, USAEC Rpt. ORNL-3576, Oak Ridge National Laboratory (April 1964).

8. S. J. Rimshaw, Isotopic Power Data Sheets, USAEC Rpt. TID-7698 (Pt. I), Conf. on Isotopic Power Development, Germantown, Maryland, May 18-19, 1964 .

9. C. A. Rohrmann, Radioisotopic Heat Sources, USAEC Rpt. HW-76323, Hanford Laboratories (February 1963).

10. R. A. Robinson et al., Brayton-Cycle Radioisotope Heat Source Design Study, Phase I (Conceptual Design) Report, USAEC Rpt. ORNL-TM-1691-de1., Oak Ridge National Laboratory (August 1967), pp. 107-13.

11. B. B. Cunningham and J. C. Wallmann, Crystal Structure and Melting Point of Curium Metal, J. Inorg. Nucl. Chem. 26: 271-5 (1964).

12. D. B. McWhan, B. B. Cunningham, and J. C. Wallmann, Crystal Structure, Thermal Expansion, and Melting Point of Americium Metal, J. Inorg. Nucl. Chem. 24: 1025-38 (1962).

13. K. A. Gschneidner, Solid State Physics, F. Seitz and D. Turnbull, eds., Vol. 16, Academic Press, 1964.

14. J. A. Gibson et al., The Properties of the Rare Earth Metals and Compounds, Battelle Memorial Institute, Columbus, Ohio, May 1959.

15. B. B. Cunningham, Compounds of the Actinides, in Preparative Inorganic Reactions, Vol. 3, William L. Jolly (ed.), Interscience Publishers, New York, 1966, pp. 79-121. 
16. H. S. Hilborn (comp.), Savannah River Laboratory Isotopic Power and Heat Sources, Quarterly Progress Report, January-March 1968, USAEC Rpt. DP-1155-II, Savannah River Laboratory (classified).

17. H. S. Hilborn (comp.), Savannah River Laboratory Isotopic Power and Heat Sources, Quarterly Progress Report, April-June 1968, USAEC Rpt. DP-l169-II, Savannah River Laboratory (classified).

18. S. N. Lvov, V. F. Nemchenko, and Yu. B. Paderno, Thermal Conductivities of the Alkaline Earth and Rare Earth Hexaborides, Dokl. Akad. Nauk SSSR 146(6): 1371-2 (1963).

19. E. N. da C. Andrade, A Theory of the Viscosity of Liquids - Part II, Phil. Mag. 17: 698-732 (1934).

20. 0. Flint, Surface Tension of Liquid Metals (a review), British Rpt. AERE-M-1479 (November 1964).

21. R. N. Karlsson, The Total Hemispherical Emittance of Polished and Oxidized Alpha Plutonium, USAEC Rpt. RFP-616, The Dow Chemical Company (July 1965).

22. R. C. Weast, S. M. Selby, and C. D. Hodgman, Handbook of Chemistry and Physics, 45th ed., The Chemistry Rubber Company, Cleveland, Ohio, 1964.

23. J. I. Burnett, Oak Ridge National Laboratory, private communication, November 1965.

24. T. Lyman, ed., Metals Handbook, 8th Ed., Vol. 1, Properties and Selection of Metals, American Society for Metals, Metals Park, Novelty, Ohio, 196I.

25. R. M. Dell and M. Allbutt, The Nitrides of Uranium, Thorium, and Plutonium. A Review of Present knowledge, British Rpt. AERE-R-4253 (March 1963).

26. U. S. Department of Commerce, National Bureau of Standards, Maximum Permissible Body Burdens and Maximum Permissible Concentrations of Radionuclides in Air and in Water for Occupational Exposure, Handbook 69 (June 5, 1959).

27. J. C. Posey, P. R. Kuehn, and R. E. McHenry, The Influence of Temperature and Oxygen Pressure on the Composition of Curium Oxide, presented at the Am. Chem. Soc. Meeting, Atlantic City, New Jersey, September 1965.

28. T. D. Chikalla and L. Eyring, The Curium-Oxygen System, USAEC Rpt. BNWL-CC-1569, Pacific Northwest Laboratory (February 13, 1968).

29. W. C. Mosley, B-Type ${ }^{244} \mathrm{Cm}_{2} \mathrm{O}_{3}$ - A Candidate Isotopic Power Fuel, Abstracts of Papers, 155th National Meeting, Am. Chem. Soc., San Francisco, California, April 1968, No. 0-173. 
30. H. S. Hilborn (comp.), Savannah River Laboratory Isotopic Power and Heat Sources, Quarterly Progress Report, January-March 1967, USAEC Rpt. DP-I105-II, Savannah River Laboratory (classified).

31. H. S. Hilborn (comp.), Savannah River Laboratory Isotopic Power and Heat Sources, Quarterly Progress Report, April-June 1967, USAEC Rpt. DP-II20-II, Savannah River Laboratory (classified).

32. H. S. Hilborn (comp.), Savannah River Laboratory Isotopic Power and Heat Sources, Quarterly Progress Report, October-December 1967, USAEC Rpt. DP-1.143-II, Savannah River Laboratory (classified).

33. A. Glassner, The Thermochemical Properties of the Oxides, Fluorides, and Chlorides to $2500^{\circ} \mathrm{K}$, USAEC Rpt. ANL-5750, Argonne National Laboratory (1957).

34. H. S. Hilborn (comp.), Savannah River Laboratory Isotopic Power and Heat Sources, Quarterly Progress Report, July-September 1966, USAEC Rpt. DP-1088, Savannah River Laboratory (classified).

35. H. S. Hilborn (comp.), Savannah River Laboratory Isotopic Power and Heat Sources, Quarterly Progress Report, July-September 1967, USAEC Rpt. DP-1129-II, Savannah River Laboratory (classified).

36. P. K. Smith, Melting Point of $\mathrm{Cm}_{2} \mathrm{O}_{3}$, J. Inorg. Nucl. Chem. (to be published).

37. P. K. Smith and D. E. Peterson, High Temperature Evaporation and Thermodynamic Properties of $\mathrm{Cm}_{2} \mathrm{O}_{3}$, Abstracts of Papers, 155th National Meeting, Am. Chem. Soc., San Francisco, California, April 1968, No. 0-031.

38. J. C. Posey, Oak Ridge National Laboratory, unpublished data, April 1968.

39. T. D. Chikalla, Pacific Northwest Laboratory, unpublished data, April 1968.

40. H. S. Hilborn (comp.), Savannah River Laboratory Isotopic Power and Heat Sources, Quarterly Progress Report, October-December 1966, USAEC Rpt. DP-1094, Savannah River Laboratory.

41. Herman 0. Haug, Curium Sesquioxide $\mathrm{Cm}_{2} \mathrm{O}_{3}$, J. Inorg. Nucl. Chem. 29: 2753-58 (1967).

42. P. Angelini and R. E. McHenry, Diffusion of Helium in Curium-244 Fuel Forms, Abstracts of Papers, 155th National Meeting, Am. Chem. Soc., San Francisco, California, April 1968, No. 0-174.

43. J. R. Hague et al. (eds.), Refractory Ceramics for Aerospace, American Ceramics Society, Columbus, Ohio, 1964. 
44. W. R. McDonell et al., Curium-244 for Radioisotopic Heat Sources Work at Savannah River Laboratory, USAEC Rpt. DP-1066, Vol. II, Savannah River Laboratory (May 1966).

45. E. F. Westrum, Jr., and Fredrik Gronvold, Thermochemical Data of Actinide Element Chalcogenides, in Thermodynamics of Nuclear Materials, International Atomic Energy Agency, Vienna, 1962, p. 28.

46. W. H. Zachariasen, Crystal Chemical Studies of the 5-f Series of Elements, VII. The Crystal Structure of $\mathrm{Ce}_{2} \mathrm{O}_{2} \mathrm{~S}$, $\mathrm{La}_{2} \mathrm{O}_{2} \mathrm{~S}$, and $\mathrm{Pu}_{2} \mathrm{O}_{2} \mathrm{~S}$, Acta Cryst. 2: 60-2 (1949).

47. E. D. Eastman et al., Preparation and Properties of the Oxide-Sulfides of Cerium, Zirconium, Thorium, and Uranium, J. Am. Chem. Soc. 73: 3896-9 (1951).

48. G. V. Samsonov and S. V. Radzikovskaya, The Chemistry of Rare Earth and Actinide Sulfides, Russian Chemical Reviews, 30: 28-41 (1961).

49. W. Latimer, Oxidation Potentials, Prentice-Hall, Inc., Englewood Cliffs, New Jersey, 1952.

50. A. N. Hodge, The Fluorides of the Actinide Elements in Advances in Fluorine Chemistry, Vol. 2, Butterworth, London, 1961, pp. 138-82.

51. D. B. Sirdeshmukh and V. T. Desphande, Temperature Variation of the Lattice Constants and the Coefficients of Thermal Expansion of Some Fluoride Type Crystals, Indian J. Pure Appl. Phys. 2(12): 405-7 (1964).

52. J. Burnett, Melting Points of $\mathrm{CmF}_{3}$ and $\mathrm{AmF}_{3}$, J. Inorg. Nucl. Chem. 28: $2454-6(1966)$.

53. S. C. Carnigler and B. B. Cunningham, Vapor Pressures of Americium Trifluoride and Plutonium Trifluoride, Heats and Free Energies of Sublimation, J. Am. Chem. Soc. 77: 1451-3 (1955).

54. K. A. McCarthy and S. S. Ballard, Thermal Conductivity of Eight Halide Crystals in the Temperature Range $220^{\circ} \mathrm{K}$ to $390^{\circ} \mathrm{K}$, J. Appl. Phys. 31(8): 1410-2 (1960).

55. L. B. Asprey, T. K. Keenan, and F. H. Kruse, Crystal Structures of the Trifluorides, Trichlorides, Tribromides, and Triiodides of Americium and Curium, J. Inorg. Chem. 4(7): 985-6 (1965).

56. H. A. O'Brien, Jr., Oak Ridge National Laboratory, private communication, April 24, 1963. 
-

0 


\author{
ORNL-4357 \\ UC-4 - Chemistry
}

INTERNAL DISTRIBUTION

1. Biology Library

2-4. Central Research Library

5-6. ORNL - Y-12 Technical Library Document Reference Section

7-41. Laboratory Records Department

42. Laboratory Records, ORNL R.C.

43. R. G. Affel

44. P. S. Baker

45. Russell Baldock

46. R. D. Baybarz

47. E. E. Beauchamp

48. C. E. Bemis, Jr.

49. J. E. Bigelow

50. D. S. Billington

51. F. T. Binford

52. G. E. Boyd

53. W. D. Burch

54. J. Burnett

55. T. A. Butler

56. F. N. Case

57. T. G. Clark

58. J. W. Cleland

59. T. F. Connolly

60. W. Davis, Jr.

61. J. R. Distefano

62. C. Feldman

63. F. J. Furman

64. J. H. Gillette

65. K. W. Haff

66. F. E. Harrington

67. J. D. Hoeschele

68. R. W. Horton

69. H. B. Hupf

70. H. Inouye

71. D. Jacobs
72-73. E. E. Ketchen

74. R. H. Lafferty, Jr.

75. E. Lamb

76. C. E. Larson

77. R. J. Lauer

78. K. H. Lin

79. H. G. MacPherson

80. H. A. Mahlman

81. H. F. McDuffie

82. R. E. McHenry

83. J. R. McWherter

84. F. L. Moore

85. R. G. Niemeyer

86. P. B. Orr

87. C. L. Ottinger

88. J. J. Pinajian

89. J. K. Poggenburg

90-114. S. J. Rimshaw

1I5. R. A. Robinson

116. P. S. Rudolph

117. A. F. Rupp

118. H. T. Russell

119. R. W. Schaich

120. J. R. Sites

121. M. J. Skinner

122. H. M. Smith

123. D. A. Sundberg

124. J. R. Tarrant

125. W. A. Thomas

126. W. E. Unger

127. A. M. Weinberg

128. R. C. Weir

129. J. C. White

130. J. P. Witherspoon

131. R. G. Wymer

\title{
EXTERNAL DISTRIBUTION
}

132. Director, Division of Space Nuclear Systems, AEC, Washington, D.C.

133. Director, Division of Reactor Development and Technology, AEC, Washington, D.C.

134-136. Director, Division of Isotopes Development, AEC, Washington, D.C.

137. Director, Division of Production, AEC, Washington, D.C.

138. Assistant Director, Space Electric Power Office, SNS-AEC, Washington, D.C.

139. Chief, Isotope Power Systems Branch, SEPO-SNS-AEC, Washington, D.C. 
140. Chief, Advanced Engine Branch, SNS-AEC, Washington, D.C.

141. Chief, Safety Branch, SEPO-SNS-AEC, Washington, D.C.

142. Chief, Space Isotopes and Materials Branch, SEPO-SNS-AEC, Washington, D.C.

143. Chief, Isotopic Auxiliary Power Branch, DRD and T-AEC, Washington, D.C.

144. Assistant Director, Nuclear Safety Office, DRD and T-AEC. Washington, D.C.

145. J. A. Swartout, Union Carbide Corporation, New York

146. Laboratory and University Division, AEC, ORO

147-356. Given distribution as shown in TID-4500 under Chemistry category (25 copies - CFSTI) 